\begin{tabular}{|c|l|}
\hline Title & Characterization of a $\beta$-D-mannosidase from a marine gastropod, A plysia kurodai \\
\hline Author(s) & Zahura, Umme A fsari; Rahman, Mohammad Matiur; Inoue, A kira; Ojima, Takao \\
\hline Citation & $\begin{array}{l}\text { Comparative Biochemistry and Physiology Part B: Biochemistry and Molecular Biology, 162(1-3), 2433 33 } \\
\text { https://doi.org/10.1016/.cbpb.2012.02.003 }\end{array}$ \\
\hline Issue Date & 2012-05 \\
\hline Doc URL & http://hdl.handle.net/2115/49356 \\
\hline Type & article (author version) \\
\hline File Information & CBPB162-1-3_2433.pdf \\
\hline
\end{tabular}

Instructions for use 


\title{
Characterization of a $\beta$-D-mannosidase from a marine gastropod, Aplysia kurodai
}

\author{
Umme Afsari Zahura, Mohammad Matiur Rahman, Akira Inoue, and Takao Ojima* \\ ${ }^{1}$ Laboratory of Marine Biotechnology and Microbiology, Graduate School of Fisheries Sciences, \\ Hokkaido University, Minato-cho 3-1-1, Hakodate 041-8611, Japan
}

*Corresponding author: Tel: +81 13840 8800; fax: +81 138408800 .

E-mail address: ojima@fish.hokudai.ac.jp (T. Ojima) 


\section{Abstract}

A $\beta$-D-mannosidase (EC 3.2.1.25) with a molecular mass of approximately $100 \mathrm{kDa}$ was purified from the digestive fluid of a marine gastropod Aplysia kurodai by ammonium sulfate fractionation followed by column chromatographies on TOYOPEARL Butyl-650 M, TOYOPEARL DEAE650 M, and Superdex 200 10/300 GL. This enzyme, named AkMnsd in the present study, showed optimal activities at $\mathrm{pH} 4.5$ and $40^{\circ} \mathrm{C}$ and was stable at the acidic $\mathrm{pH}$ range from 2.0 to 6.7 and the temperature below $38^{\circ} \mathrm{C}$. The $K \mathrm{~m}$ and $V \max$ values for $\mathrm{AkMnsd}$ determined at $\mathrm{pH} 6.0$ and $30^{\circ} \mathrm{C}$ with p-nitrophenyl $\beta$-D-mannopyranoside were $0.10 \mathrm{mM}$ and $3.75 \mu \mathrm{mol} / \mathrm{min} / \mathrm{mg}$, respectively. AkMnsd degraded various polymer mannans as well as mannooligosaccharides liberating mannose as a major degradation product. Linear mannan from green alga Codium fragile was completely depolymerized by AkMnsd in the presence of AkMan, an endolytic $\beta$-mannanase, which we previously isolated from the same animal (Zahura et al., Comp. Biochem. Physiol., B 157, 137-148 (2010)). A cDNA encoding AkMnsd was amplified from the Aplysia hepatopancreas cDNA by the PCR using degenerated primers designed on the basis of $\mathrm{N}$-terminal and internal amino-acid sequences of AkMnsd. The cloned AkMnsd cDNA consisted of $2985 \mathrm{bp}$ and encoded an amino-acid sequence of 931 residues with the calculated molecular mass of 101970 Da. The deduced sequence of AkMnsd showed 20-43\% amino-acid identity to those of glycoside-hydrolase-family 2 (GHF2) $\beta$ mannosidases. The catalytically important amino-acid residues determined in GHF2 enzymes were completely conserved in AkMnsd. Thus, AkMnsd is regarded as a new member of GHF2 mannosidase from marine gastropod.

Key words: Aplysia kurodai; gastropod; $\beta$-mannosidase; $\beta$-1,4-mannan; mannooligosaccharides. 


\section{Introduction}

$\beta$-1,4-Mannan, a major hemicellulosic constituent of plants' tissues, is classified into four types of mannan on the basis of sugar composition and side-chain structure, i.e., linear mannan, galactomannan, glucomannan and galactoglucomannan (Moreira and Filho, 2008). Linear mannan is a homopolysaccharide that comprises a linear chain of 1,4-linked $\beta$-D-mannopyranosyl residues containing less than $5 \%$ of galactose residues. Linear mannan exists as a structural polysaccharide in fronds of marine algae such as Porphyra umbilicalis and Codium fragile (Moreira and Filho, 2008), wood and beans in terrestrial plants (Aspinall, 1959), and endosperm of Palmae (Petkowicz et al., 2001). In nature, mannans appear to be consumed mainly by microorganisms which can depolymerize mannans into mannose with mannan-degrading enzymes. In aquatic environment, mannans in algal fronds and their detritus are consumed not only by microorganisms but also by benthic animals such as annelids, arthropods and mollusks. These invertebrates also possess mannandegrading enzymes and assimilate the mannans as a carbon and energy sources (Chuang and Yang, 1991; Xu et al., 2002a; Song et al., 2008; Ootsuka et al., 2006; Zahura et al., 2010). For complete depolymerization of mannan, at least two types of mannan-degrading enzymes are necessary. One is the $\beta$-1,4-mannanase (EC 3.2.1.78, term $\beta$-mannanase in the present study) that degrades polymer mannans in an endolytic manner. Another is the $\beta$-D-mannosidase (EC 3.2.1.25, term $\beta$-mannosidase in the present study) that degrades mannan-oligosaccharides to mannose units. Since $\beta$-mannosidase is usually capable of releasing the mannose from the nonreducing terminus of polymer mannans, this enzyme is occasionally called as an exolytic mannanase.

Mannan-degrading enzymes are useful in various industrial processes. For example, $\beta$ mannanase improves the clarity of instant coffee and fruit juice, and promotes pulp bleaching in paper industry (Moreira and Filho, 2008). On the other hand, $\beta$-mannosidase is useful for 
saccharification of mannans from decayed plant materials in a nutritional purpose for farm animals. $\beta$-Mannosidase is also useful for the production of biofuels and bioplastics since this enzyme can produce fermentable sugar from hemicellulosic materials (Moreira and Filho, 2008). Since $\beta$ mannosidase is important for releasing of mannose residues of $\mathrm{N}$-glycosyl proteins in lysosome, defect of lysosomal $\beta$-mannosidase causes accumulation of mannosidic intermediates in cytosol and gives rise to the relating diseases (Neufeld, 1991). Thus, $\beta$-mannosidase has been attracting attentions in such medical fields (Kobata, 1993).

Interest in mannan-degrading enzymes from different sources has been increasing in the past decade especially from the viewpoint of biotechnological application (Singh et al., 2003). While many studies have been focusing on the endolytic mannan-degrading enzymes, i.e., $\beta$-mannanases from plants, bacteria, fungi, and invertebrates, not so much attention has been paid to $\beta$-mannosidase. To date, characterization and primary structure analysis of $\beta$-mannosidase have been achieved in a few enzymes from bacteria (Duffaud et al., 1997; Stoll et al., 2000; Beki et al., 2003), fungi (Takada et al., 1999; Ademark et al., 2001), and mammals (Chen et al., 1995; Leipprandt et al., 1996; Alkhayat et al., 1998; Beccari et al., 2001). On the basis of the hydrophobic cluster analysis for their primary structures, most of these $\beta$-mannosidases were classified under glycosyl hydrolase-family 2 (GHF2) (Chen et al., 1995; Alkhayat et al., 1998; Takada et al., 1999; Ademark et al., 2001). Occurrence of $\beta$-mannosidase has also been reported in some mollusks (Sugahara et al., 1972; McCleary, 1983; Muramatsu, 1966; Andreotti et al., 2005); however, there appears no report on the primary structure of molluscan $\beta$-mannosidase. Thus, the GHF to which the molluscan $\beta$ mannosidases belongs has not been revealed.

Recently, we isolated and characterized AkMan, a $\beta$-mannanase from a common sea hare Aplysia kurodai, and determined its primary structure by cDNA cloning (Zahura et al., 2010 and 2011). A. kurodai is known as a typical herbivorous marine mollusk which possesses various kinds 
of polysaccharide-degrading enzymes, e.g., alginate lyase (Rahman et al., 2010 and 2011) and laminarinase (Kumagai and Ojima, 2010) in addition to $\beta$-mannanase (Zahura et al., 2010 and 2011). These enzymes are considered to play important roles for the degradation of seaweeds' polysaccharides in A. kurodai and providing the carbohydrate nutrients for this animal. As for the mannan degradation, AkMan splits the internal $\beta$-1,4-mannosyl linkages of the seaweeds' $\beta$-mannan producing tri- and disaccharides. But this enzyme could not produce mannose (Zahura et al., 2010).

On the other hand, we recently noticed that digestive fluid (crude enzyme) of A. kurodai can produce mannose from various mannan substrates. This implied that the digestive fluid of $A$. kurodai contained $\beta$-mannosidase.

Therefore, in the present study, we attempted to isolate the $\beta$-mannosidase from A. kurodai. As a result, a $\beta$-mannosidase, named AkMnsd in the present study, was successfully isolated from the digestive fluid. Further, we succeeded to clone the cDNA encoding AkMnsd and analyzed the primary structure of this enzyme. As far as we know, this is the first report on the cDNA cloning and primary structure analysis for $\beta$-mannosidase from invertebrates.

\section{Materials and methods}

\subsection{Materials}

A synthetic substrate, $p$-nitrophenyl $\beta$-D-mannopyranoside, was purchased from SigmaAldrich Co. (Tokyo, Japan). Locust bean gum (galactomannan with a molar ratio for mannose:galactose is $4: 1$ ) was kindly supplied by MRC POLYSACCHARIDE Co. Ltd. (Toyama, Japan). Mannooligosaccharides (mannobiose mannohexaose, M2 M6) were from Megazyme (Bray, Ireland) and the other chemicals with reagent grade were from Wako Pure Chemical Industries Ltd. 
(Osaka, Japan). Linear mannan was prepared from C. fragile according to the method of Love and Percival (1964). This mannan preparation comprised of approximately $90 \%$ of mannose and less than $5 \%$ of galactose and contained no appreciable amount of oligosaccharides. TOYOPEARL DEAE$650 \mathrm{M}$ and TOYOPEARL Butyl-650 M were from Toyo Soda Mfg. Co. (Tokyo, Japan), and Superdex 200 10/300 GL from GE Healthcare UK Ltd. (Little Chalfont, Bucking Ham shire, England).

Digestive fluid was obtained from the stomach lumen of $A$. kurodai (body length, $\sim 12 \mathrm{~cm}$ ), which was collected in the summer of 2009 from the shore of Hakodate, Hokkaido, Japan. The digestive fluid from 12 animals (approximately $90 \mathrm{~mL}$ ) was dialyzed against $2 \mathrm{mM}$ sodium phosphate buffer $(\mathrm{pH} \mathrm{7.0)}$ for $5 \mathrm{~h}$ and centrifuged at $10000 \times \mathrm{g}$ for $15 \mathrm{~min}$ to remove insoluble materials, and used for the purification of $\beta$-mannosidase. To prepare mRNA of A. kurodai, hepatopancreas was excised from an A. kurodai anesthetized in ice-water. The hepatopancreas was immediately frozen with liquid nitrogen and had been stored at $-80^{\circ} \mathrm{C}$ until RNA extraction. TA PCR cloning kit (pTAC-1) was purchased from Biodynamics (Tokyo, Japan). Oligotex-dT(30), cDNA synthesis kit, 5'- and 3'-Full RACE kits, restriction endonucleases, T4 DNA ligase, and Escherichia coli strain DH5 $\alpha$ were purchased from TaKaRa (Tokyo, Japan). AmpliTaq Gold PCR Master Mix and BigDye-Terminator Cycle Sequencing kit were from Applied Biosystems (Foster city, CA, USA). Bacto tryptone, Bacto yeast extract and other reagents used were from Wako Pure Chemicals Industries Ltd.

\subsection{Purification of AkMnsd from A. kurodai}

Crude enzyme from A. kurodai (approximately $90 \mathrm{~mL}$ ) was first subjected to ammonium sulfate fractionation. The highest $\beta$-mannosidase activity was detected in the fraction precipitated 
between $40-70 \%$ saturation of ammonium sulfate. This fraction was dissolved in $10 \mathrm{mM}$ sodium phosphate buffer ( $\mathrm{pH}$ 6.0) containing 40\% saturation of ammonium sulfate and dialyzed against the same buffer for $24 \mathrm{~h}$. The dialysate was centrifuged at $10000 \times \mathrm{g}$ for $20 \mathrm{~min}$, and the supernatant was applied to a TOYOPEARL Butyl-650 M column $(1.5 \mathrm{~cm} \times 20 \mathrm{~cm})$ pre-equilibrated with the same buffer. The proteins adsorbed to the column was eluted by a stepwise elution system consisting of 40\%-, 30\%-, 10\%- and 0\%- saturation of ammonium sulfate (each $375 \mathrm{~mL}$ ) at a flow rate of $15 \mathrm{~mL} / \mathrm{h}$. The eluent was collected as $15 \mathrm{~mL}$ fractions. $\beta$-Mannosidase activity was detected in the fractions eluted with $10 \%$ saturation of ammonium sulfate. The active fractions were pooled and dialyzed against $10 \mathrm{mM}$ sodium phosphate buffer ( $\mathrm{pH}$ 6.0). A small amount of aggregates formed during dialysis was removed by centrifugation at $10000 \times \mathrm{g}$ for $10 \mathrm{~min}$, and the supernatant was subjected to TOYOPEARL DEAE-650M column $(1.5 \mathrm{~cm} \times 23 \mathrm{~cm})$ pre-equilibrated with $10 \mathrm{mM}$ sodium phosphate buffer ( $\mathrm{pH}$ 6.0). Proteins adsorbed to the column were eluted with a linear gradient of 0 $0.2 \mathrm{M} \mathrm{NaCl}$ at a flow rate of $15 \mathrm{~mL} / \mathrm{h}$. Active fractions showing $\beta$-mannosidase activity were pooled, dialyzed against $10 \mathrm{mM}$ sodium phosphate buffer $(\mathrm{pH} 6.0$ ), and lyophilized. The pellets were dissolved in $10 \mathrm{mM}$ sodium phosphate buffer ( $\mathrm{pH}$ 6.0) containing $0.05 \mathrm{M} \mathrm{NaCl}$, dialyzed against the same buffer and subjected to gel-filtration through Superdex 200 10/300 GL column installed in AKTA-FPLC (GE Healthcare UK Ltd.). Proteins were eluted with $10 \mathrm{mM}$ sodium phosphate buffer ( $\mathrm{pH}$ 6.0) containing $0.05 \mathrm{M} \mathrm{NaCl}$ at a flow rate of $60 \mathrm{~mL} / \mathrm{h}$. Active fractions were pooled and subjected again to the same column. The second gel-filtration gave a single peak with $\beta$-mannosidase activity and the thus purified protein showed a single band with approximately $100 \mathrm{kDa}$ on SDSPAGE (Fig. 1). We named this enzyme AkMnsd.

\subsection{Assay for $\beta$-mannosidase activity}


$\beta$-Mannosidase activity was assayed at $30^{\circ} \mathrm{C}$ in a $1 \mathrm{~mL}$ of reaction medium containing 2.5 $\mathrm{mM}$-nitrophenyl $\beta$-D-mannopyranoside, $10 \mathrm{mM}$ sodium citrate buffer $(\mathrm{pH} 4.5)$ and an appropriate amount of enzyme. The reaction was terminated in $15 \mathrm{~min}$ by the addition of $2 \mathrm{~mL}$ of $0.1 \mathrm{M} \mathrm{Na}_{2} \mathrm{CO}_{3}$ to the reaction medium and the $p$-nitrophenol produced was determined by measuring the absorbance at $410 \mathrm{~nm}$. One unit of $\beta$-mannosidase activity was defined as the amount of enzyme catalyzing the release of $1.0 \mu \mathrm{mol}$ of $p$-nitrophenol per minute under the assay conditions. The average values for triplicate measurements were adopted as activity values.

\subsection{SDS-PAGE}

SDS-Polyacrylamide gel electrophoresis was carried out with $0.1 \%$ (w/v) SDS-10\% (w/v) polyacrylamide slab gel according to the method of Porzio and Pearson (1977). After the electrophoresis, the gel was stained with $0.1 \%$ (w/v) Coomassie Brilliant Blue R-250 in 50\% (v/v) methanol-10\% (v/v) acetic acid, and the background of the gel was destained with 5\% (v/v) methanol-7\% (v/v) acetic acid. Protein Marker, Broad Range (New England BioLabs, Ipswich, MA, USA) was used as a molecular mass marker.

\subsection{Determination of protein concentration}

Protein concentration was determined by the biuret method (Gornall et al., 1949) or the method of Lowry et al. (1951) using bovine serum albumin fraction V as a standard protein.

\section{6. $p H$ and thermal stabilities of AkMnsd}


To determine the optimum $\mathrm{pH}$ of AkMnsd activity, the following buffers were used to adjust the $\mathrm{pH}$ of reaction mixtures; $\mathrm{pH}$ 2.0-3.0 with $10 \mathrm{mM}$ glycine- $\mathrm{HCl}$, $\mathrm{pH}$ 3.0-6.0 with $10 \mathrm{mM}$ citrate$\mathrm{NaOH}$, and $\mathrm{pH}$ 6.0-8.3 with $10 \mathrm{mM}$ sodium phosphate. To assess $\mathrm{pH}$ stability of the enzyme, AkMnsd was first incubated at $40^{\circ} \mathrm{C}$ for $20 \mathrm{~min}$ in $50 \mathrm{mM}$ sodium phosphate buffer adjusted to $\mathrm{pH}$ 2.0-9.0, then an aliquot of the incubated medium (usually $0.1 \mathrm{~mL}$ ) was added to $0.9 \mathrm{~mL}$ of reaction mixture containing $2.5 \mathrm{mM}$-nitrophenyl $\beta$-D-mannopyranoside and $50 \mathrm{mM}$ sodium phosphate buffer $\left(\mathrm{pH}\right.$ 6.0) and the activity was measured at $30^{\circ} \mathrm{C}$. The $\mathrm{pH}$ for the reaction medium was maintained at around 6 during the reaction. Optimum temperature of the enzyme was assessed by measuring the activity at $15-60^{\circ} \mathrm{C}$. Thermal stability was assessed by measuring the activity remaining after the heat treatment at $15-55^{\circ} \mathrm{C}$ for $20 \mathrm{~min}$.

\subsection{Enzyme kinetics}

To determine the kinetic parameters, i.e., the Michaelis-Menten constant $(K \mathrm{~m})$ and the maximal reaction velocity ( $V \max$ ), of AkMnsd, the activity was determined with various concentrations $(0.1,0.5,1.0,2.0,3.0,4.0$, and $5.0 \mathrm{mM})$ of $p$-nitrophenyl $\beta$-D-mannopyranoside. Other reaction conditions were the same as the standard conditions. $K_{\mathrm{m}}$ and $V_{\max }$ values were estimated from the Lineweaver-Burk plot.

\subsection{Thin-layer chromatography of degradation products of mannan and mannooligosaccharides}

Degradation products of mannan and mannooligosaccharides produced by AkMnsd were analyzed by thin-layer chromatography (TLC) as follows. Linear mannan from C. fragile and mannooligosaccharides (M2-M6) were dissolved in $10 \mathrm{mM}$ sodium phosphate buffer ( $\mathrm{pH}$ 6.0) to 
make a final concentration of $0.5 \%(\mathrm{w} / \mathrm{v})$. To $25 \mu \mathrm{L}$ of each substrate solution, $25 \mu \mathrm{L}$ of $\beta$ mannosidase ( 0.25 units) was added to initiate reaction and the mixture was incubated at $30^{\circ} \mathrm{C}$ for 24 h. Linear mannan was degraded in $100 \mu \mathrm{L}$ of reaction mixture at $30^{\circ} \mathrm{C}$ and at an appropriate time interval $10 \mu \mathrm{L}$ of samples were withdrawn from the reaction mixture. The samples were then heated at $100^{\circ} \mathrm{C}$ for $2 \mathrm{~min}$ to terminate the reaction. Two micro litters of each reaction mixture were applied to a TLC-60 plate (Merck, Darmstadt, Germany) and developed with 1-butanol-acetic acid-water $(2: 1: 1, \mathrm{v}: \mathrm{v}: \mathrm{v})$. The sugars developed on the plate were visualized by heating at $110^{\circ} \mathrm{C}$ for $15 \mathrm{~min}$ after spraying $10 \%(\mathrm{v} / \mathrm{v})$ sulfuric acid in ethanol.

\subsection{Determination of cooperative action of AkMnsd and AkMan on mannan substrates}

To examine the cooperative action of $\beta$-mannosidase (AkMnsd) and $\beta$-mannanase (AkMan), two mannan substrates, i.e., linear mannan and galactomannan were used as substrates. The $0.5 \mathrm{~mL}$ of reaction mixture containing $2.5 \mathrm{mg} / \mathrm{mL}$ of each substrate in $10 \mathrm{mM}$ sodium phosphate buffer (pH 6.0) and $25 \mu \mathrm{L}\left(0.25\right.$ unit) of each enzyme was incubated at $30^{\circ} \mathrm{C}$ for $0-24 \mathrm{~h}$. An aliquot $(10 \mu \mathrm{L})$ of the reaction mixture was withdrawn at appropriate time intervals and heated at $100^{\circ} \mathrm{C}$ for 2 min to inactive the enzymes. The degradation products were analyzed by TLC as described above.

\subsection{Determination of $N$-terminal and internal amino-acid sequences}

The N-terminal amino-acid sequence of AkMnsd was determined with an ABI Procise 492 protein sequencer (Applied Biosystems, Foster City, CA, USA). The purified protein was dialyzed against $10 \%$ acetonitrile- $0.1 \%$ trifluoroacetic acid (TFA) and concentrated by a centrifugal evaporator and subjected to the protein sequencer. Internal peptide sequences of AkMnsd were 
determined with a matrix-assisted laser desorption ionization-time of flight mass spectrometry (MALDI-TOF MS) by using an ABI Proteomics Analyzer 4700 (Applied Biosystems, Foster city, CA, USA). For this purpose, the purified protein sample was subjected to SDS-PAGE, and the target band was excised from the gel, cut into pieces of $\sim 1 \mathrm{~mm}^{3}$, destained and dehydrated with solution (50\% acetonitrile in $25 \mathrm{mM} \mathrm{NH}_{4} \mathrm{HCO}_{3}$ ) and $100 \%$ acetonitrile, respectively. The gel pieces were dried with a centrifugal evaporator and swollen with a reducing agent $(10 \mathrm{mM}$ dithiothreitol in 25 $\mathrm{mM} \mathrm{NH} \mathrm{HCO}_{3}$ ), washed with $25 \mathrm{mM} \mathrm{NH}_{4} \mathrm{HCO}_{3}$ and alkylated with $55 \mathrm{mM} \mathrm{ICH} \mathrm{CONH}_{2}$ in $25 \mathrm{mM}$ $\mathrm{NH}_{4} \mathrm{HCO}_{3}$. The gel pieces were dehydrated again with $50 \%$ acetonitrile in $25 \mathrm{mM} \mathrm{NH}_{4} \mathrm{HCO}_{3}$ and dried up completely in a vacuum desiccator. The protein in the gel pieces was then digested with 0.1 $\mu \mathrm{g} / \mathrm{mL}$ trypsin in $25 \mathrm{mM} \mathrm{NH} \mathrm{HCO}_{3}$ at $37^{\circ} \mathrm{C}$ for $16 \mathrm{~h}$. Peptide fragments were then extracted from the gel pieces with $50 \%(\mathrm{v} / \mathrm{v})$ acetonitrile in $5 \%(\mathrm{v} / \mathrm{v})$ TFA and dried with a centrifugal evaporator. The peptides were dissolved in $0.1 \%$ (v/v) TFA and desalted with ZipTip (MILLIPORE, Billerica, MA, USA). The peptides bound to ZipTip were finally guanidinated by the method of Wang et al. (2004) and subjected to an ABI 4700 proteomics analyzer (Applied Biosystems). Amino-acid sequences of the peptides were analyzed by DeNovo Explorer software in a MS/MS mode (Applied Biosystems). Homology searches for the amino-acid sequences on the public databases were performed with the FASTA and BLAST programs (http://fasta.ddbj.nig.ac.jp/top-j.html, http://blast.ddbj.nig.ac.jp/topj.html) provided by DNA Data Bank of Japan.

\subsection{1. cDNA cloning and nucleotide sequencing}

Total RNA of A. kurodai was extracted from $1 \mathrm{~g}$ of hepatopancreas, which had been stored at $-80^{\circ} \mathrm{C}$ after quick freezing with liquid nitrogen, by the guanidinium thiocyanate-phenol method (Chomczynski and Sacchi, 1987) and mRNA was selected from the total RNA with Oligotex-dT(30) 
according to the manufacturer's protocol. Hepatopancreas cDNA was synthesized with the mRNA by using a TaKaRa cDNA synthesis kit and random hexanucleotide primers. cDNAs encoding AkMnsd were amplified from the hepatopancreas cDNA by PCR using degenerated primers synthesized on the basis of partial amino-acid sequences of AkMnsd. The PCR was performed in $20 \mu \mathrm{L}$ of reaction mixture containing $50 \mathrm{mM} \mathrm{KCl}, 15 \mathrm{mM}$ Tris- $\mathrm{HCl}(\mathrm{pH} 8.0), 0.2 \mathrm{mM}$ each of dATP, dTTP, dGTP, and $\mathrm{dCTP}, 2.5 \mathrm{mM} \mathrm{MgCl}_{2}$, and $5 \mathrm{pmol} / \mu \mathrm{L}$ primers, $1 \mathrm{ng} / \mu \mathrm{L}$ template DNA, and 0.5 units AmpliTaq Gold DNA polymerase. A successive reaction at $94^{\circ} \mathrm{C}$ for $30 \mathrm{~s}, 55^{\circ} \mathrm{C}$ for $30 \mathrm{~s}$, and $72^{\circ} \mathrm{C}$ for $90 \mathrm{~s}$ was repeated for 40 cycles with Thermal Cycler Dice mini (TaKaRa, Tokyo, Japan). The size of the amplified cDNA was estimated by $1.0 \%$ agarose-gel electrophoresis and cloned with TA PCR cloning kit (pTAC-1) (Invitrogen, CA, USA) and E. coli DH5a. The transformants were grown in 2 $\times$ YT medium supplemented by $50 \mu \mathrm{g} / \mathrm{mL}$ ampicillin at $37^{\circ} \mathrm{C}$ for $14 \mathrm{~h}$ by shaking at $150 \mathrm{rpm} / \mathrm{min}$. The plasmids extracted from the transformants were subjected to the sequence analysis with BigDyeTerminator Cycle Sequencing kit and ABI 3130xl Genetic Analyzer (Applied Biosystems). The 3'RACE and 5'-RACE PCRs were performed with specific primers synthesized on the bases of the nucleotide sequences of the amplified cDNAs according to the manufacturers' protocols.

\section{Results}

\subsection{General properties of the purified AkMnsd}

AkMnsd was purified from the digestive fluid of A. kurodai through ammonium sulfate fractionation followed by the conventional column chromatographies. In the final gel-filtration through Superdex 200 10/300 GL, AkMnsd eluted as a single peak and showed a single protein band 
with an approximate molecular mass of $100 \mathrm{kDa}$ on SDS-PAGE (Fig. 1). AkMnsd was purified 23.7fold from the crude enzyme at a recovery of $2.7 \%$ and the specific activity of $25.8 \mathrm{U} / \mathrm{mg}$ (Table 1 ).

The optimum $\mathrm{pH}$ and temperature of AkMnsd were observed at around $\mathrm{pH} 4.5$ and $40^{\circ} \mathrm{C}$, respectively (Fig. 2A and C). AkMnsd was stable at acidic $\mathrm{pH}$ conditions, i.e., 50\% of the original activity was retained after the incubation at $\mathrm{pH} 2.0-6.7$ and $40^{\circ} \mathrm{C}$ for $20 \mathrm{~min}$ (Fig. 2B). The temperature that caused a half inactivation of AkMnsd during 20 min incubation was $38^{\circ} \mathrm{C}$ (Fig. 2D).

Kinetic parameters, $K \mathrm{~m}$ and $V \max$, of AkMnsd to the substrate $p$-nitrophenyl $\beta$-Dmannopyranoside were estimated to be $0.10 \mathrm{mM}$ and $3.75 \mathrm{U} / \mathrm{mg}$, respectively.

\subsection{Degradation of mannooligosaccharides and linear mannan by AkMnsd}

To examine the activity of AkMnsd toward oligosaccharide substrates, mannooligosaccharides (M2 M6) were degraded by AkMnsd and the reaction products were analyzed by TLC (Fig. 3). AkMnsd could degrade all the oligosaccharides tested to mannose (Fig. 3A). It should be noted that the degradation of mannooligosaccharides appeared to take place exolytically. Namely, M6 was first degraded to M5 which was one mannose unit smaller than M6 and the produced M5 was then degraded to M4 which was one mannose unit smaller than M5 (Fig. 3B). This stepwise degradation seemed to continue until most of the original substrate was converted to mannose. The exolytic action of AkMnsd was also seen in a linear $\beta$-mannan substrate (Fig. 3C). Thus, AkMnsd produced only mannose from the linear $\beta$-mannan without any intermediate oligosaccharides. These analyses for the degradation products strongly suggested that AkMnsd acted on the substrates in an exolytic manner.

\subsection{Cooperative action of AkMnsd and AkMan on mannan}


As mentioned in the "Introduction" part, AkMan, an endolytic $\beta$-mannanase of $A$. kurodai, may degrade seaweeds' mannan together with AkMnsd to produce mannose efficiently. As shown in Fig. 4A, the linear mannan was readily degraded by the action of AkMan and AkMnsd to mannotriose and mannobiose in the early stage of the reaction, and then converted to mannose in the later stage. The amount of mannose produced by the two enzymes was considerably higher than that produced by AkMnsd alone (see Fig. 3C). On the other hand, AkMan and AkMnsd degraded locust bean gum (galactomannan) to produce not only mannose but also hexasaccharide, pentasaccharide and trisaccharide (Fig. 4B). These oligosaccharides may be derived from galactose-branching regions. Namely, the galactose branches of locust bean gum may inhibit the actions of AkMan and AkMnsd and make the branching regions undigested.

\section{4. cDNA cloning and primary structure of AkMnsd}

The N-terminal amino-acid sequence of 40 residues of AkMnsd was determined as YERVPLDGQLNWMLSEASAGVNIPASVPGSMYTALLEKNL by the protein sequencer. This sequence showed $22.5 \%$ amino-acid identity with the GHF2 $\beta$-mannosidases from Homo sapiens (Alkhayat et al., 1998; DDBJ accession number, U60337) and Caenorhabditis elegans (DDBJ accession number, $\underline{\mathbf{Z 7 8 5 4 0}}$ ), $27.5 \%$ identity with the enzymes from Aspergillus aculeatus (DDBJ accession number, $\underline{\mathbf{A B 0 1 5 5 0 9}}$ ). The sequences of tryptic fragments of AkMnsd (Table 2) also showed 10-80\% identities with the sequences of GHF2 $\beta$-mannosidases from various organisms. Such sequence similarity of AkMnsd to GHF2 enzymes suggested that AkMnsd also belongs to GHF2. 
cDNAs encoding AkMnsd were amplified by PCR. First, AkMnsd-cDNA-1, consisting of $1791 \mathrm{bp}$ and encoding an amino-acid sequence of 597 residues, was amplified by PCR with the degenerated forward and reverse primers, AkMnsdFw and AkMnsdRv, which were designed on the basis of N-terminal and an internal amino-acid sequences of AkMnsd, respectively (Table 3). Then 3'-RACE and 5'-RACE PCRs were performed with the specific primers shown in Table 3 and cDNA-3RACE (1077bp) and cDNA-5RACE (437bp) were amplified, respectively. By overlapping the nucleotide sequences of cDNA-5RACE, AkMnsd-cDNA-1 and cDNA-3RACE, in this order, the nucleotide sequence of total 2985 bp including the complete translational region of AkMnsd was determined (Fig. 5). In this sequence, the translational initiation codon, ATG, was found to locate in the nucleotide positions from 107 to 109 and termination codon, TAG, from 2900 to 2902. Accordingly, the amino-acid sequence of 931 residues was deduced from the translational region of 2793 bp which spans 107-2899th nucleotides. In the 3'-terminal region, a putative polyadenylation signal sequence, AATGAA, and a poly $(\mathrm{A}+)$ tail-like sequence were found. The $\mathrm{N}$-terminal region of 14 residues except for the initiation Met, i.e., FWFHVSLLIATGIS, was predicted as the signal peptide for secretion by the Signal P3.0 software (http://www.cbs.dtu.dk/services/SignalP/). The sequence of 12 amino acids, QWMLKTNNLVSS, which locates just after the signal peptide, was regarded as a propeptide-like region of this enzyme since this region was absent in the native AkMnsd protein. Therefore, the mature AkMnsd was considered to consist of 904 amino-acid residues with the calculated molecular mass of $101970 \mathrm{Da}$. This molecular mass is well consistent with the molecular mass, $100 \mathrm{kDa}$, estimated by SDS-PAGE (see Fig. 1). All the internal peptide sequences of T-1 to T-5 (Table 2) are seen in the deduced sequence (Fig. 5). Thus, the cDNA was concluded to be of AkMnsd. (the nucleotide and the deduced amino-acid sequences are available from the DNA Data Bank of Japan with the accession number AB685732).

We compared the deduced amino-acid sequence of AkMnsd with those of several $\beta$ - 
mannosidases belonging to glycoside hydrolase family 2 (GHF2) (Fig. 6). The amino-acid sequence of AkMnsd showed 43\%, 24\% and 20\% identities with $\beta$-mannosidases from $H$. sapiens (Alkhayat et al., 1998), A. aculeatus (Takada et al., 1999) and C. elegans (DDBJ accession number, $\underline{\mathbf{Z 7 8 5 4 0}}$ ), respectively. The two glutamate residues which are known as the common catalytic residues of GHF2 were conserved as Glu467 and Glu563 in the deduced sequence of AkMnsd (Fig. 6). Accordingly, AkMnsd from A. kurodai was concluded as an enzyme belonging to GHF2.

\section{Discussion}

During the purification of $\beta$-1,4-mannanase from A. kurodai (Zahura et al., 2010), we noticed the occurrence of $\beta$-mannosidase(s) in the crude enzyme preparation. In the present study, we successfully purified the $\beta$-mannosidase, AkMnsd, from the crude enzyme. The molecular mass of AkMnsd was estimated to be $100 \mathrm{kDa}$ by SDS-PAGE. Since the molecular masses of $\beta$ mannosidases from other organisms were in a range of 94-135 kDa, e.g., Helix pomatia, $94 \mathrm{kDa}$ (McCleary, 1983); Aplysia fasciata, $130 \mathrm{kDa}$ (Andreotti et al., 2005); Aspergillus niger, $135 \mathrm{kDa}$ (Ademark et al., 1999); Thermobifida fusca TM51, 94 kDa (Beki et al., 2003); Aspergillus aculeatus No.F-50, 104 kDa (Takada et al.,1999); Tricoderma reesei, 105 5 kDa (Kulminskaya et al., 1999); and A. niger, $102.335 \mathrm{kDa}$ (Ademark et al., 2001), the molecular mass of AkMnsd was found to be comparable with those of other $\beta$-mannosidases.

The optimum $\mathrm{pH}$ and temperature of AkMnsd was $\mathrm{pH} 4.5$ and $40^{\circ} \mathrm{C}$, respectively (Fig. $2 \mathrm{~A}$ and 2C). A $\beta$-mannosidase from A. fasciata showed similar optimal pH, i.e., $\mathrm{pH} 4.5$ (Andreotti et al., 2005), whereas it showed higher optimal temperature $45^{\circ} \mathrm{C}$, which is 5 degrees higher than that of AkMnsd. On the other hand, the optimum $\mathrm{pH}$ and temperature of $\beta$-mannosidase from a terrestrial mollusk, H. pomatia, were at $\mathrm{pH} 4.0$ and $55^{\circ} \mathrm{C}$ (McCleary, 1983). Most of fungal $\beta$-mannosidases 
showed optimal activity in acidic pHs, i.e., pH 2.4-5.0 for A. niger (Ademark et al., 1999) and pH 3.5 for T. reesei (Kulminskaya et al., 1999). AkMnsd was considerably stable at acidic $\mathrm{pH}$ conditions. Namely, the activity retained $50 \%$ after the incubation at $40^{\circ} \mathrm{C}$ for $20 \mathrm{~min}$ in the $\mathrm{pH}$ range of $2.0-6.7$ (Fig. 2B). $\beta$-Mannosidases from some organisms also showed similar $\mathrm{pH}$ stability in acidic conditions. For example, T. reesei enzyme was stable in a pH range of 3.5-6.0 (Kulminskaya et al., 1999) and A. niger enzyme was stable at $\mathrm{pH}$ 4.0-6.0 (Ademark et al., 1999). However, thermal stability of AkMnsd in the acidic $\mathrm{pH}$ range was somewhat lower compared with $\beta$-mannosidases from A. niger (Bouquelet et al., 1978) and Thermotoga neapolitana 5068 (Duffaud et al., 1997). Thus, A. niger enzyme was not inactivated by the incubation at $50^{\circ} \mathrm{C}$ for $24 \mathrm{~h}$ and T. neapolitana 5068 enzyme showed half-lives of $18 \mathrm{~h}$ at $85^{\circ} \mathrm{C}, 42 \mathrm{~min}$ at $90^{\circ} \mathrm{C}$, and $2 \mathrm{~min}$ at $98^{\circ} \mathrm{C}$.

The $K \mathrm{~m}$ and $V \max$ values for AkMnsd were $0.10 \mathrm{mM}$ and $3.75 \mathrm{U} / \mathrm{mg}$, respectively. More or less similar $\mathrm{Km}$ and $V \max$ values were found in $\beta$-mannosidases from $T$. fusca TM51 ( $\mathrm{Km}=180 \mu \mathrm{M}$ and $V \max =5.96$; Beki et al., 2003) and T. reesei $(\mathrm{Km}=0.12 \mathrm{mM}$; Kulminskaya et al., 1999). On the other hand, significantly higher $K \mathrm{~m}$ and $V \max$ values were determined for the $\beta$-mannosidase from $A$. fasciata, i.e., $2.4 \mathrm{mM}$ and $50.3 \mu \mathrm{mol} / \mathrm{min} / \mathrm{mg}$, respectively (Andreotti et al., 2005). Significantly higher $\mathrm{Km}$ values i.e., $1.43 \mathrm{mM}$ and $6.5 \mathrm{mM}$ were determined for other molluscan $\beta$-mannosidase from H. pomatia (McCleary, 1983) and A. fulica (Sugahara et al., 1972), respectively. The Km values for the $\beta$-mannosidases from $H$. sapiens (Noeske and Mersmann, 1983) and A. niger (Bouquelet et al., 1978) were $2.2 \mathrm{mM}$ and $0.46 \mathrm{mM}$, respectively. Thus, the $\mathrm{Km}$ value for AkMnsd was considered to be more similar to those of fungal enzymes than those of other molluscan enzymes.

AkMnsd could degrade various sizes of mannooligosaccharides (M2 M6) (Fig. 3A). This indicated that AkMnsd is a typical $\beta$-D-mannosidase. When mannohexaose (M6) was degraded by AkMnsd, mannose unit was released along with the stepwise decreasing of the substrate size from M6 to M2 (Fig. 3B). This result indicated that AkMnsd exolytically cleaved the $\beta-1,4$-mannosidic 
bond of mannooligosaccharides. Such an exotype action has been found in the mannosidases from a terrestrial snail, H. pomatia (McCleary, 1983) and A. niger (Ademark et al., 1999) and these enzymes were shown to act on the non-reducing terminus of substrates.

AkMnsd was capable of degrading not only mannooligosaccharides but also polymer mannan. When linear mannan was degraded by AkMnsd, mannose was produced as a major product (Fig. 3C). This result indicated that AkMnsd acted on polymer substrate with an exolytic manner. On the other hand, when linear mannan was degraded by both AkMnsd and AkMan, linear mannan was more efficiently degraded to mannose accompanying the production of some intermediate oligosaccharides (Fig. 4A). This indicated that AkMnsd and AkMan could act on the seaweed's mannan cooperatively in the digestive fluid of $A$. kurodai to produce mannose efficiently. On the other hand, when locust bean gum, a galactomannan, was degraded by the two enzymes, some oligosaccharides were remained to be undigested (Fig. 4B). The apparent sizes of the oligosaccharide were tri-, penta- and hexasaccharides. This suggests that AkMnsd and AkMan hardly degrade the branching region of galactomannan. Consequently, the remained tri-, penta- and hexaoligosaccharides were considered to be oligosaccharides possessing galactose branches. The higher order structures of such oligosaccharides will be determined in future.

The nucleotide sequence of AkMnsd cDNA which encodes the amino-acid sequence of 931 residues was determined. The deduced sequence comprised the initiation Met, the putative signal peptide of 14 residues, the propeptide-like region of 12 residues, and mature enzyme region of 904 residues. The calculated molecular mass of the mature enzyme region was $101970 \mathrm{Da}$, which was well consistent with the molecular mass of native AkMnsd (approximately $100 \mathrm{kDa}$ ) estimated by SDS-PAGE. The amino-acid sequence of the mature enzyme region showed $20 \sim 43 \%$ identities with those of GHF2 $\beta$-mannosidases from animal and fungus sources (Alkhayat et al., 1998; Takada et al., 1999). GHF2 includes various types of polysaccharide-degrading enzymes such as $\beta$-galactosidase, 
$\beta$-glucuronidase, exo- $\beta$-glucosaminidase (Llanillo et al., 1977; Diez and Cabezas, 1978; Nogawa et al., 1998). Such GHF2 enzymes, two glutamate residues are known as catalytically important. According to the three-dimensional structures of $\beta$-glucuronidases from human (Jain et al., 1996) and E. coli (Jacobson et al., 1994), the two glutamate residues i.e., Glu457 and Glu554 for H. sapiens and Glu461 and Glu537 for E. coli were found to participate in the catalytic action. These Glu residues are conserved in $\beta$-mannosidases from $H$. sapiens, A. aculeatus and C. elegans (Fig. 6) and also in AkMnsd as Glu467 and Glu563. One glutamate residue (Glu519) in a $\beta$-mannosidase from $C$. fimi was revealed to be the catalytic nucleophile (Stoll et al., 2000). These conserved Glu residue in AkMnsd indicated that this enzyme is a new member of GHF2 $\beta$-mannosidase.

\section{Acknowledgment}

This study was supported in part by the grants for project research (Development of fundamental technology for analysis and evaluation of functional agricultural products and functional foods), Ministry of Agriculture, Forestry and Fisheries, Japan. The authors appreciate Mr. Hiroyuki Tanaka for his assistance in mass spectrometry.

\section{References}

Ademark, P., Lundqvist, J., Hagglund, P., Tenkanen, M., Torto, N., Tjerneld, F., Stalbrand, H., 1999. Hydrolytic properties of a $\beta$-mannosidase purified from Aspergillus niger. J. Biotechnol. 75, 281-289.

Ademark, P., de Vries, R.P., Hagglund, P., Stalbrand, H., Visser, J., 2001. Cloning and chracterization of Aspergillus niger genes encoding an $\alpha$-galactosidase and a $\beta$-mannosidase involved in galactomannan degradation. Eur. J. Biochem. 268, 2982-2990. 
Alkhayat, A.H., Kraemer, S.A., Leipprandt, J.R., Macek, M., Kleijer, W.J., Friderici, K.H., 1998. Human $\beta$-mannosidase cDNA characterization and first identification of a mutation associated with human $\beta$-mannosidosis. Hum. Mol. Genet. 7, 75-83.

Andreotti, G., Giordano, A., Tramice, A., Mollo, E., Trincone, A., 2005. Purification and characterization of a $\beta$-mannosidase from the marine anaspidean Aplysia fasciata. J. Biotechnol. $119,26-35$.

Aspinall, G.O., 1959. Structural chemistry of the hemicelluloses. Adv. Carbohydr. Chem. 14, 429468.

Beccari, T., Bibi, L., Stinchi, S., Stirling, J.L., Orlacchio, A., 2001. Mouse beta-mannosidase: cDNA cloning, expression, and chromosomal localization. Biosci. Rep. 21, 315-323.

Bouquelet, S., Spik, G., Monteuil, J., 1978. Properties of a $\beta$-mannosidase from Aspergillus niger. Biochim. Biophys. Acta. 522, 521-530.

Béki, E., Nagy, I., Vanderleyden, J., Jager, S., Kiss, L., Fülöp, L., Hornok, L., Kukolya, J., 2003. Cloning and Heterologus Expression of a $\beta$-D-mannosidase (EC 3.2.1.25)-Encoding gene from Thermobifida fusca TM51. Appl. Environ. Microbiol. 1944-1952.

Chen, H., Leipprandt, J.R., Traviss, C.E., Sopher, B.L., Jones, M.Z., Cavanagh, K.T., Friderici, K.H., 1995. Molecular cloning and characterization of bovine $\beta$-mannosidase. J. Biol. Chem. 270, 3841-3848.

Chomczynski, P., Sacchi, N., 1987. Single step method of RNA isolation by acid guanidinium thiocyanate-phenol-chloroform extraction. Ana. Biochem. 162, 156-159.

Chuang, N.N., Yang, B.C., 1991. Purification and properties of a beta-mannosidase from shrimp (Penaeus japonicus) hepatopancreas. Comp. Biochem. Physiol. B. 98, 627-630.

Diez, T., Cabezas, J.A., 1978 . Properties of two molecular forms of $\beta$-glucuronidase from the mollusc Littorina littorea L. Eur. J. Biochem. 93, 301-311. 
Duffaud, G.D., McCutchen, C.M., Leduc, P., Parker, K.N., Kelly, R.M., 1997. Purification and characterization of extremely thermostable beta-mannanase, beta-mannosidase, and alphagalactosidase from hyperthermofilic eubacterium Thermotoga neapolitana 5068. Appl. Environ. Microbiol. 63,169-177.

Gornall, A.G., Bardawill, C.J., David, M.M., 1949. Determination of serum proteins by means of the biuret reaction. J. Biol. Chem. 177, 751-766.

Jacobson, R.H., Zhang, X.-J., Dubose, R.F., Matthews, B.W., 1994. Three-dimensional structure of $\beta$-galactosidase from E. coli. Nature 369, 761-766.

Jain, S., Drendel, W.B., Chen, Z., Mathews, F.S., Sly, W.S., Grubb, J.H., 1996. Structure of human $\beta$-glucuronidase reveals candidate lysosomal targeting and active-site motifs. Nat. Struct. Biol. 3, $375-381$.

Kobata, A., 1993. Glycobiology: an expanding research area in carbohydrate chemistry. Acc. Chem. Res. 26, 319-324.

Kulminskaya, A.A., Eneiskaya, E.V., Ludmila, S., Isaeva-Ivanova, L.S., Savel'ev, A.N., Sidorenko, I.A., Shabalin, K.A., Golubev, A.M., Neustroev, K.N., 1999. Enzymatic activity and $\beta$ galactomannan binding property of $\beta$-mannosidase from Trichoderma reesei. Enzyme Microb.Technol. 25, 372-377.

Kumagai, Y., Ojima, T., 2010. Isolation and characterization of two types of beta-1,3-glucanases from the common sea hare Aplysia kurodai. Comp. Biochem. Physiol. B 155, 138-144.

Leipprandt, J.R., Kraemer, S.A., Haithcock, B.E., Chen, H., Dyme, J.L., Cavanagh, K.T., Friderici, K.H., Jones, M.Z., 1996. Caprine $\beta$-mannosidase: sequencing and characterization of the cDNA and identification of the molecular defect of caprine $\beta$-mannosidosis. Genomics 37, 51-56.

Llanillo, M., Perez, N., Cabezas, J.A., 1977. $\beta$-Galactosidase and $\beta$-glucosidase activities of the same enzyme from rabbit liver. Int. J. Biochem. 8, 557-564. 
Love, J., Percival, E., 1964. The polysaccharides of green seaweed Codium fragile. Part III. A $\beta$ linked mannan. J. Chem. Soc. 3345-3350.

Lowry, O.H., Rosebrough, N.J., Farr, A.L., Randall, R.J., 1951. Protein measurement with the Folin phenol reagent. J. Biol. Chem. 193, 265-275.

McCleary, B.V., 1983. $\beta$-D-Mannosidase from Helix pomatia. Carbohydr. Res. 111, 297-310.

Moreira, L.R., Filho, E.X., 2008. An overview of mannan structure and mannan-degrading enzyme systems. Appl. Microbiol. Biotechnol. 79, 165-178.

Muramatsu, T., 1966. Purification of $\alpha$-D-mannosidase and $\beta$-D-mannosidase from marine gastropods. Arch. Biochem. Biophys. 115, 427-429.

Neufeld, E.F., 1991. Lysosomal storage diseases. Annu. Rev. Biochem. 60, 257-280.

Noeske, C., Mersmann, G., 1983. $\beta$-D-Mannosidase from human placenta: properties and partial purification. Hoppe-Seyler's Z. Physiol. Chem. 364, 1645-1651.

Nogawa, M., Takahashi, H., Kashiwagi, A., Ohshima, K., Okada, H., Morikawa, Y., 1998. Purification and characterization of exo- $\beta$-D-glucosaminidase from a cellulolytic fungus, Trichoderma reesei PC-3-7. Appl. Environ. Microbiol. 64, 890-895.

Ootsuka, S., Saga, N., Suzuki, K., Inoue, A., Ojima, T., 2006. Isolation and cloning of an endo- $\beta-1,4-$ mannanase from Pacific abalone Haliotis discus hannai. J. Biotechnol.125, 269-280.

Petkowicz, C.L.O., Reicher, F., Chanzy, H., Taravel, F.R., Vuong, R., 2001. Linear mannan in the endosperm of Schizolobium amazonicum. Carbohydr. Polym. 44, 107-112.

Porzio, M.A., Pearson, A.M., 1977. Improved resolution of myofibrillar proteins with sodium dodecyl sulfate-polyacrylamide gel electrophoresis. Biochim. Biophys. Acta. 490, 27-34.

Rahman, M.M., Inoue, A., Tanaka, H., Ojima, T., 2010. Isolation and characterization of two alginate lyase isozymes, AkAly28 and AkAly33, from the common sea hare Aplysia kurodai. Comp. Biochem. Physiol. B 157, 317-325. 
Rahman, M.M., Inoue, A., Tanaka, H., Ojima, T., 2011. cDNA cloning of an alginate lyase from a marine gastropod Aplysia kurodai and assessment of catalytic important residues of this enzyme. Biochimie 93, 1720-1730.

Singh, S., Madlala, A.M., prior, B.A., 2003. Thermomyces lanuginosus: properties of strains and their hemicellulases. FEMS. Microbiol. Rev. 27, 3-16.

Song, J.M., Nam, K.W., Kang, S.G., Kim, C.G., Kwon, S.T., Lee, Y.H., 2008. Molecular cloning and characterization of a novel cold-active $\beta$-1,4-D-mannanase from the antartic springtail, Cryptopygus antarcticus. Comp. Biochem. Physiol. B. 151, 32-40.

Stoll, D., He, S., Withers, S.G., Warren, R.A.J., 2000. Identification of glu-519 as the catalytic nucleophile in $\beta$-mannosidase 2A from Cellulomonas fimi. Biochem. J. 351, 833-838.

Sugahara, K., Okumura, T., Yamashina, I., 1972. Purification of $\beta$-mannosidase from a snail , Achatina fulica and its action on glycopeptides. Biochim. Biophys. Acta. 268, 448-496.

Takada, G., Kawaguchi, T., Kaga, T., Sumitani, J., Arai, M., 1999. Cloning and sequencing of $\beta$ mannosidase gene from Aspergillus aculeatus no. F-50. Biosci. Biotechnol. Biochem. 63, 206209.

Wang, D., Kalb, S.R., Cotter, R.J., 2004. Improved procedures for N-terminal sulfonation of peptides for matrix-assisted laser desorption/ionization post-source decay peptide sequencing. Rapid Commun. Mass Spectrom. 18, 96-102.

Xu, B., Hägglund, P., Stalbrand, H., Janson, J.C., 2002a. Endo- $\beta-1,4-$ mannanases from blue mussel, Mytilus edulis: purification, characterization and mode of action. J. Biotechnol. 92, 267-277.

Zahura, U.A., Rahman, M.M., Inoue, A., Tanaka, H., Ojima, T., 2010. An endo- $\beta$-1,4-mannanase, AkMan, from the common sea hare Aplysia kurodai. Comp. Biochem. Physiol. B 157, 137-143.

Zahura, U.A., Rahman, M.M., Inoue, A., Tanaka, H., Ojima, T., 2011. cDNA cloning and bacterial expression of an endo- $\beta-1,4-m a n n a n a s e$, AkMan, from Aplysia kurodai. Comp. Biochem. 
Physiol. B 159, 227-235. 


\section{Legends to figures}

Fig. 1. The second gel-filtration of AkMnsd through Superdex 200 10/300 GL. The AkMnsd fraction obtained in the first gel-filtration through a Superdex 200 10/300 GL was subjected to the second gel-filtration. Fractions indicated by the horizontal solid bar were pooled. SDS-PAGE for $\beta$ mannosidase preparations from A. kurodai is shown in the inset. Lane 1, marker protein; lane 2, the crude enzyme; Lane 3, the sample after TOYOPEARL Butyl-650 M; Lane 4, the sample after TOYOPEARL DEAE-650 M; Lane 5, AkMnsd purified by the second gel-filtration through Superdex 200 10/30.

Fig. 2. Effects of $\mathrm{pH}$ and temperature on AkMnsd. (A) $\mathrm{pH}$ dependence of AkMnsd. Activity was assayed at $30^{\circ} \mathrm{C}$ in reaction mixtures containing $2.5 \mathrm{mM}$-nitrophenyl $\beta$-D-mannopyranoside adjusted to $\mathrm{pH}$ 2.0-3.0 with $10 \mathrm{mM}$ glycine- $\mathrm{HCl}(\boldsymbol{\bullet}), \mathrm{pH} 3.0-6.0$ with $10 \mathrm{mM}$ citrate- $\mathrm{NaOH}(\bullet)$ and pH 6.0-8.3 with $10 \mathrm{mM}$ sodium phosphate ( $\boldsymbol{\Delta}$ ). (B) pH stability of AkMnsd. AkMnsd was incubated at $40^{\circ} \mathrm{C}$ for $20 \mathrm{~min}$ in $50 \mathrm{mM}$ sodium phosphate buffer ( $\mathrm{pH}$ 2.0-9.0). The remaining activity was assayed at $30^{\circ} \mathrm{C}$ in a medium containing $50 \mathrm{mM}$ sodium phosphate buffer $\mathrm{pH} 6.0$ and $2.5 \mathrm{mM}$ -

nitrophenyl $\beta$-D-mannopyranoside. (C) Temperature dependence of AkMnsd. Activity was assayed at $15-60^{\circ} \mathrm{C}$ in a reaction mixture containing $2.5 \mathrm{mM} p$-nitrophenyl $\beta$-D-mannopyranoside in $10 \mathrm{mM}$ sodium phosphate buffer (pH 6.0). (D) Thermal stability of AkMnsd. The remaining activity was measured after the heat treatment at $15-55^{\circ} \mathrm{C}$ for $20 \mathrm{~min}$. 
Fig. 3. Thin-layer chromatography for degradation products of mannooligosaccharides and linear mannan produced by AkMnsd. (A) Degradation of mannose (M1) and mannooligosaccharides (mannobiose mannohexaose; M2 M6). “+E” indicates the sample after the enzyme degradation for 24 h. Mk, marker sugars; M1 M6. (B) Degradation of M6. (C) Degradation of linear mannan. The reaction mixture containing $0.5 \%$ substrate and $25 \mu \mathrm{L}$ of purified enzyme $(0.25$ unit) was mixed and allowed to react at $30^{\circ} \mathrm{C}$ for $0-24 \mathrm{~h}$ and $2 \mu \mathrm{L}$ of each reaction product was subjected to TLC.

Fig. 4. Thin-layer chromatography for degradation products of different mannans produced by the action of AkMnsd and AkMan. (A) Linear mannan degraded by AkMan and AkMnsd. (B) Locust bean gum degraded by AkMan and AkMnsd. The reaction mixture $(0.5 \mathrm{~mL})$ containing $2.5 \mathrm{mg}$ of each substrate in $10 \mathrm{mM}$ sodium phosphate buffer ( $\mathrm{pH}$ 6.0) and $25 \mu \mathrm{L}$ (0.25 unit) of each enzyme was allowed to react at $30^{\circ} \mathrm{C}$ for $0-24 \mathrm{~h}$ and $2 \mu \mathrm{L}$ of each reaction product was subjected to TLC. Hexasaccharide, pentasaccharide and trisaccharide remained undigested are indicated with "hex", "pen" and "tri”, respectively.

Fig. 5. Nucleotide and deduced amino acid sequence of AkMnsd. The translational initiation codon ATG, termination codon TAG, and a putative polyadenylation signal AATGAA are boxed. A putative signal peptide is indicated by a dotted underline. The N-terminal and the internal sequences of T-1, T-2, T-3, T-4 and T-5 are indicated with lines under the amino-acid sequence.

Fig. 6. Comparison of the amino-acid sequence of A. kurodai (AkMnsd) with GHF2 $\beta$-mannosidases. Sequences were cited from $C$. elegans (DDBJ accession number, $\underline{\text { Z78540 }}$ ), H. sapiens (DDBJ 
accession number, $\underline{\mathbf{U 6 0 3 3 7}}$ ), and A. aculeatus (DDBJ accession number, $\underline{\mathbf{A B 0 1 5 5 0 9}}$ ). Identical, highly conservative and conservative residues are indicated by asterisks $(*)$, colon (:) and dot (.) respectively. The Glu residues predicted to participate in catalytic action are boxed. 
Table 1. Summary of purification of AkMnsd.

\begin{tabular}{|c|c|c|c|c|c|}
\hline $\begin{array}{l}\text { Purification } \\
\text { steps }\end{array}$ & $\begin{array}{l}\text { Total } \\
\text { protein }(\mathrm{mg})\end{array}$ & $\begin{array}{l}\text { Total activity } \\
\text { (U) }\end{array}$ & $\begin{array}{l}\text { Specific activity } \\
\left(\mathrm{U}^{\mathrm{a}} / \mathrm{mg}\right)\end{array}$ & Yield $(\%)$ & $\begin{array}{l}\text { Purification } \\
\text { (fold) }\end{array}$ \\
\hline Crude $^{\mathrm{b}}$ & 730.36 & 795.66 & 1.09 & 100 & 1 \\
\hline Butyl $^{c}$ & 23.08 & 205.76 & 8.92 & 25.86 & 8.18 \\
\hline DEAE $^{\mathrm{d}}$ & 12.79 & 142.85 & 11.17 & 17.95 & 10.24 \\
\hline Gelfiltration $^{\mathrm{e}}$ & 2.21 & 48.15 & 21.80 & 6.05 & 20.00 \\
\hline Gelfiltration $^{\mathrm{f}}$ & 0.85 & 21.71 & 25.79 & 2.72 & 23.66 \\
\hline
\end{tabular}

${ }^{\text {a }}$ One unit of $\beta$-mannosidase activity was defined as the amount of enzyme that releases of $1.0 \mu \mathrm{mol}$ of $p$-nitrophenol per minute from $2.5 \mathrm{mM}$-nitrophenyl $\beta$-D-mannopyranoside.

${ }^{\mathrm{b}}$ Crude enzyme after the dialysis against $2 \mathrm{mM}$ sodium phosphate buffer ( $\mathrm{pH}$ 6.0).

${ }^{c}$ Active fractions obtained by TOYOPEARL Butyl-650 M chromatography.

${ }^{\mathrm{d}}$ Active fractions obtained by TOYOPEARL DEAE-650 M chromatography.

${ }^{\text {e }}$ Active fractions obtained by the first gel filtration through Superdex 200 10/300 GL.

${ }^{\mathrm{f}}$ AkMnsd purified by the second gel filtration through Superdex 200 10/300 GL. 
Table 2. N-terminal and internal amino-acid sequences of AkMnsd

Peptide $^{\mathrm{a}} \quad$ Sequence

N-terminal YERVPLDGQLNWMLSEASAGVNIPASVPGSMYTALLEKNL

T-1 EGDNSIVVGFR

T-2 INGLPVFLKGSNWIPADNFQER

T-3 TDYIYLTQINQAMSM

T-4 HAQDVSDTLAAINK

T-5 TSTSWLFLSYPK

${ }^{\mathrm{a}} \mathrm{T}-1-\mathrm{T}-5$, tryptic fragments. 
Table 3. Primers used for amplification of AkMnsd-cDNA

\begin{tabular}{llc}
\hline & Primer names & Sequences $^{\mathrm{a}, \mathrm{b}}$ \\
\hline AkMnsd-cDNA-1 & AkMnsdFw & $5^{\prime}$-GARGCNTTYGCNGGNGTNAAYATHCC-3' \\
& & ( EASAGVNIP) \\
& AkMnsdRv & $5^{\prime}$-CATNSWCATNGCYTGRTTDATYTGNGT-3' \\
& & ( TQINQAMSM) \\
cDNA-3RACE & AkMnsd(3)Fw & $5^{\prime}$-GGCTCTGCACATAGACTTGTCC- 3' \\
& 3Adapt & $5^{\prime}$-CTGATCTAGAGGTACCGGATCC- 3' \\
& AkMnsd(5)Fw & $5^{\prime}$-AGAAGTCCAGCTACGAGATCC - 3' \\
& & \\
& AkMnsd(5)Rv & $5^{\prime}$-ACAGACCAGCAGCACCTTGC - 3' \\
\hline
\end{tabular}

${ }^{a} \mathrm{R}$, adenine or guanine; $\mathrm{N}$, adenine or guanine or cytosine or thymine; $\mathrm{Y}$, cytosine or thymine; $\mathrm{H}$, adenine or cytosine or thymine; $\mathrm{S}$, cytosine or guanine; $\mathrm{W}$, adenine or thymine; and $\mathrm{D}$, adenine or guanine or thymine.

${ }^{\mathrm{b}}$ Amino-acid sequences used for designing the degenerated primers are in the parentheses. 
Fig. 1

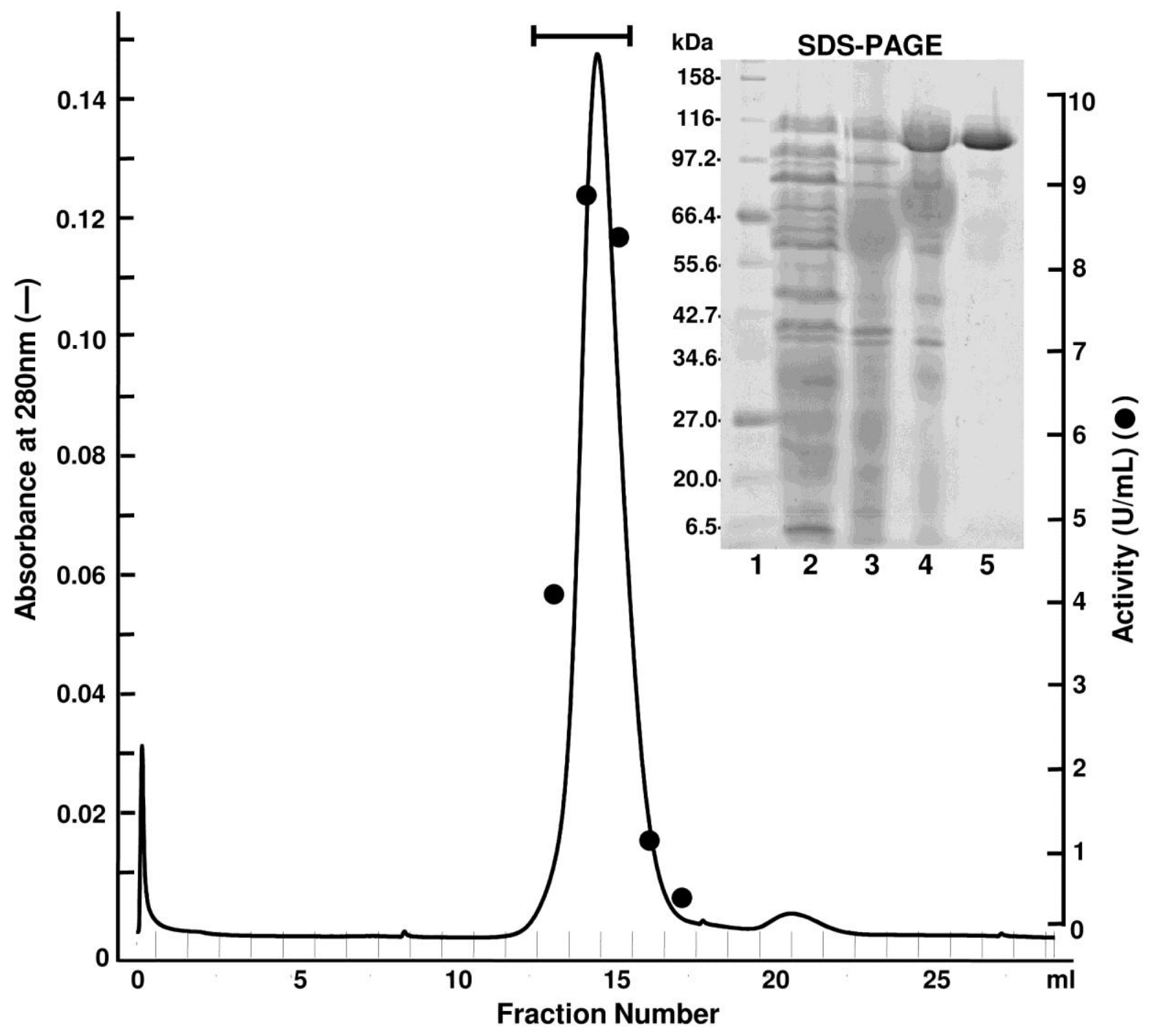


Fig. 2

(A)
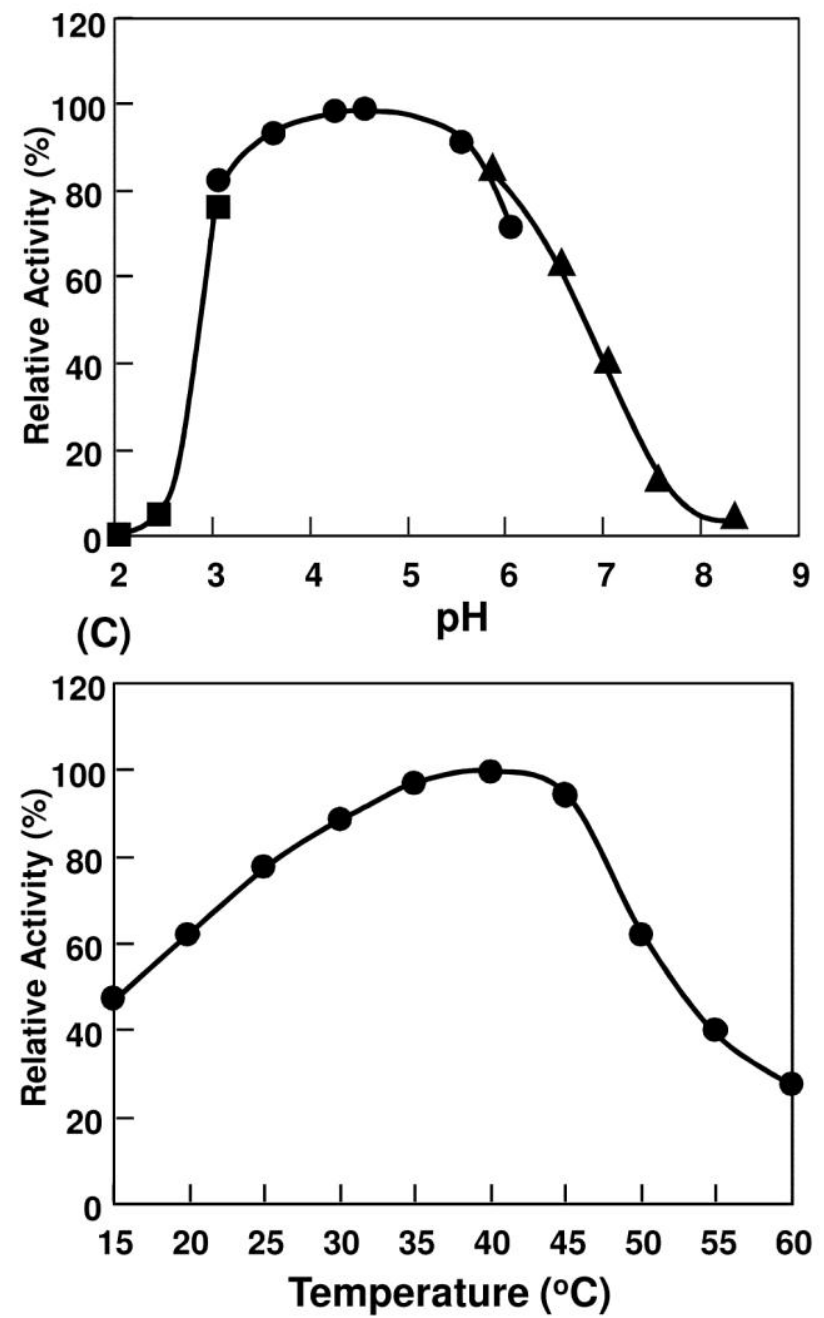

(B)
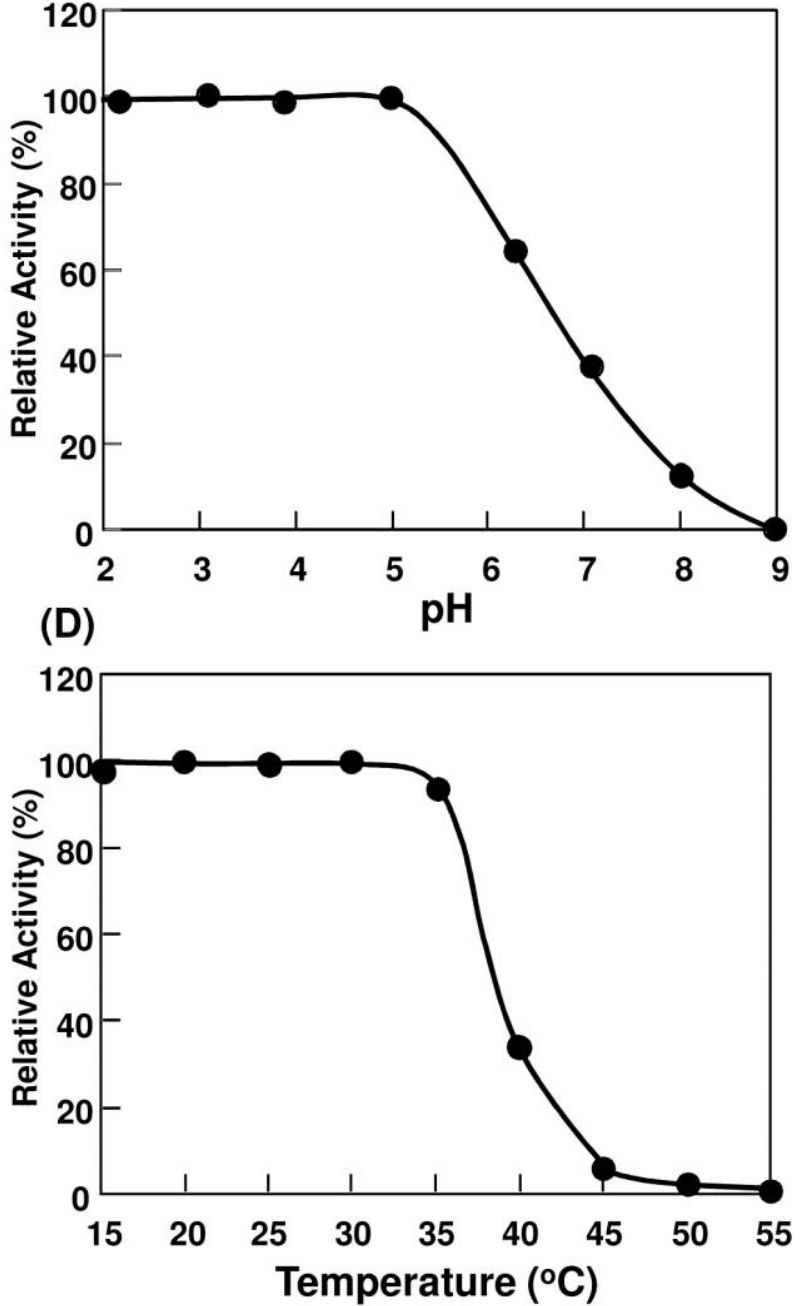
Fig. 3
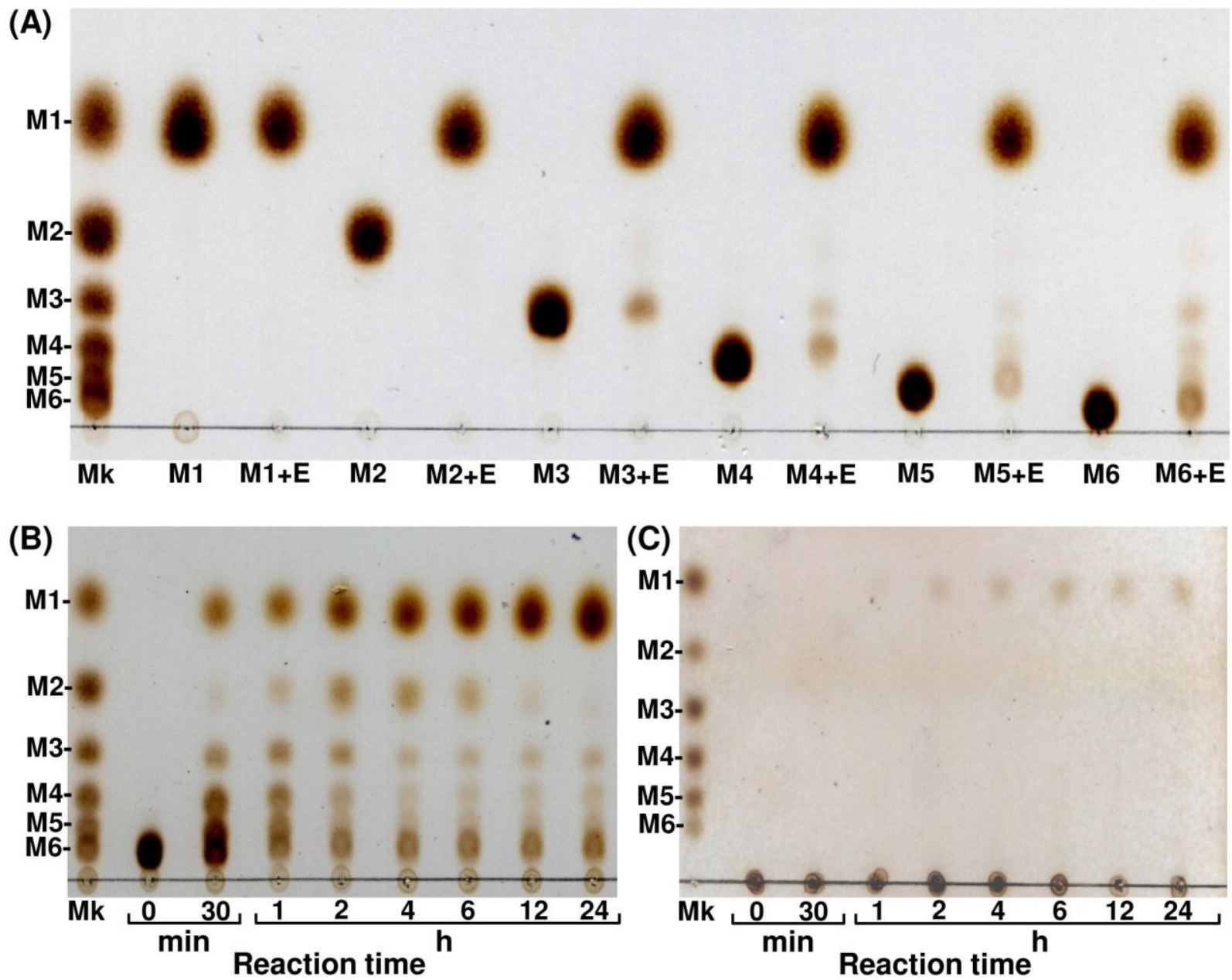
Fig. 4

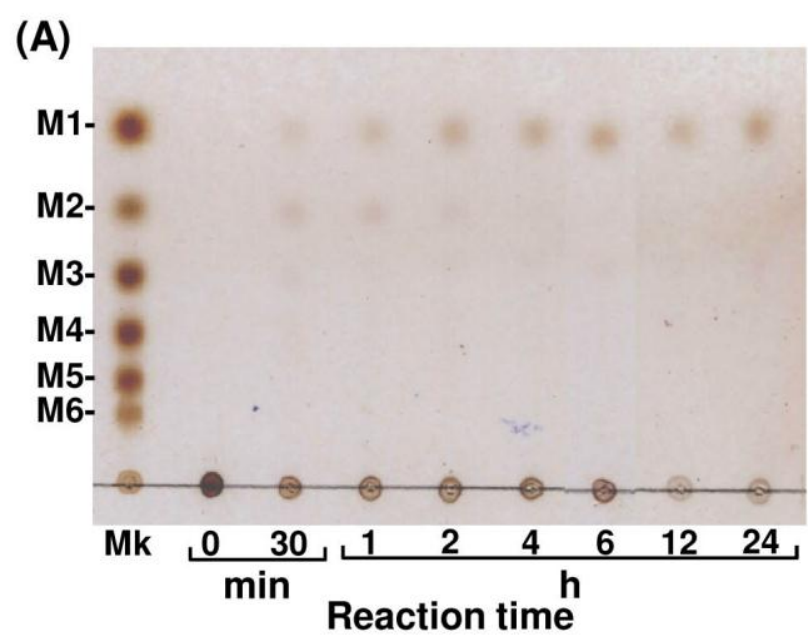

(B)

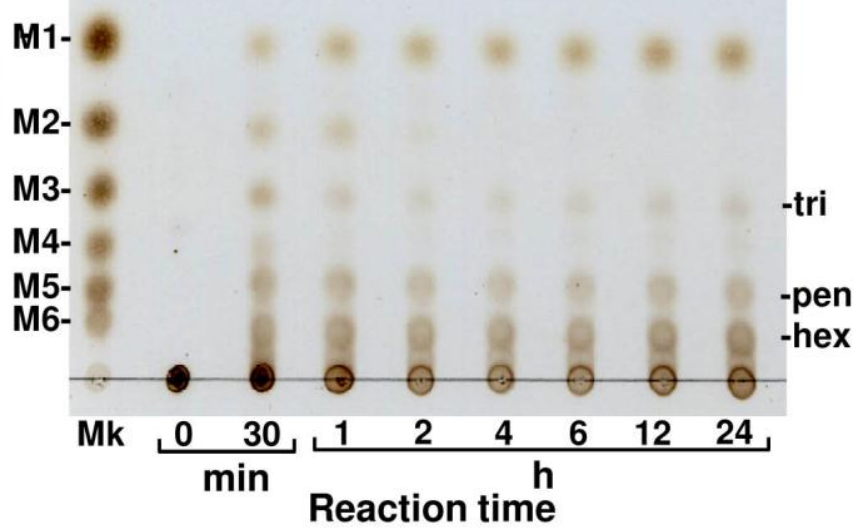




\section{Fig. 5}

AGAA GTCCAGC TACGAGATCCCGCCCAAC TGTCCACCCCCG GTCCAGCAA GGCAGT TCACAA GTGTCGCTGGCA GCA GAA GAACCACAGACT GCGGCA TA GGCAAAATGTTTGGTTCCACGTCTCGCT TCT GAT TGC TAC TGGCAT TTCACA GTG GAT GCTCAAAACGAATAA TTT GGT CAGCTC TTA TGAACGGGT TC M E $\quad$ F___. CTCTCGATGGCCAGCTTAATTGGATGTTGTCA GAGGCATCT GCA GGT GTGAATATACCGGCGTCT GTCCCCGGA TCCATG TACACGGCTCTGTTGGAAAA $\begin{array}{llllllllllllllllllllllllllllllllll}P & L & D & G & Q & L & N & W & M & L & S & E & A & S & A & G & V & N & I & P & A & S & V & P & G & S & M & Y & T & A & L & L & E & K\end{array}$ N-terminus
GAACCTCATCCAAGACCCTCTATCGGGACAACGACAACAAATATGCCT GGT TGGGTAACTCGGACT GGACGTACAACA GGAACT TCACAGTGTCCAAA

$\begin{array}{lllllllllllllllllllllllllllllllllllllll}\mathrm{N} & \mathrm{L} & \mathrm{I} & \mathrm{Q} & \mathrm{D} & \mathrm{P} & \mathrm{L} & \mathrm{Y} & \mathrm{R} & \mathrm{D} & \mathrm{N} & \mathrm{D} & \mathrm{N} & \mathrm{K} & \mathrm{Y} & \mathrm{A} & \mathrm{W} & \mathrm{L} & \mathrm{G} & \mathrm{N} & \mathrm{S} & \mathrm{D} & \mathrm{W} & \mathrm{T} & \mathrm{Y} & \mathrm{N} & \mathrm{R} & \mathrm{N} & \mathrm{F} & \mathrm{T} & \mathrm{V} & \mathrm{S} & \mathrm{K}\end{array}$ TCT GT GGC TGA GTCCAGCAAGGT GCT GCT GGTCTGTGA GGGGCT GGA CACAGT GGC GTCAGTCGT GGT CAACGGAAA GGCAGT GGGCGACACAGACAACA $\begin{array}{lllllllllllllllllllllllllllllllllllll}S & V & A & E & S & S & K & V & L & L & V & C & E & G & L & D & T & V & A & S & V & V & V & N & G & K & A & V & G & D & T & D & N\end{array}$ TGTTT GTCCGCCAT GCC TTT GACGTCACCGGGATCGTGAAGGAA GGT GACAACAGTATT GTCGTAGGC TTCCGGTCA GCGGTGCTT GAGGCACAGGAGCG $\begin{array}{llllllllllllllllllllllllllllllllllllllll}M & F & V & R & H & A & F & D & V & T & G & I & V & K & E & G & D & N & S & I & V & V & G & F & R & S & A & V & L & E & A & Q & E & R\end{array}$ CGACCAGAAGTCCAGCTACGAGA TCCCGCCCAACT GTCCACCCCCGG TCCAGCAAGGCCAGT GTCACG TGAACCAGC TGA GGAAGGAGCAGT GTA GCT TC

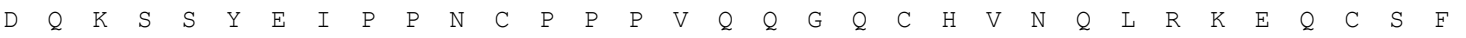
AGCTGGGACTGGGGACCCTCCTTCCCCACACA GGGCATCTGGAA GCCAATCTATCT GAATGC GTT TAG TACCGC CGTAGT GCAACGAGTCTCCGC TATAC

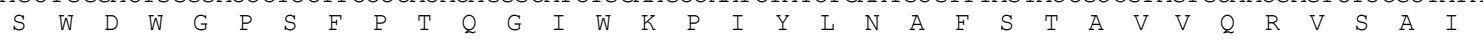
CTAAGAAAGTGAGT GGACAGTGGCAGGTGGACGTGGATGTAATCTTT GAT GTCAACGAGGGTTTAACA GAGGTCAAGGGTCAAGTGCAAGTGGACGTACC

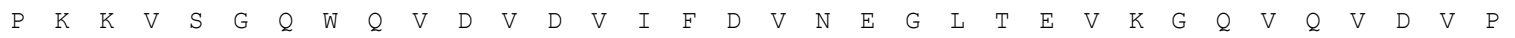
GGCCT TGAACT TGACCT TGGTTCAGGACGTGA CAGTTTCTTCCTCCCAGA GCA GGGCTAAGG TCGTAC TCAAAG TGCCGC TGGCCA GGGATG TGC TGC TG

$\begin{array}{lllllllllllllllllllllllllllllllllll}A & L & N & L & T & L & V & Q & D & V & T & V & S & S & S & Q & S & R & A & K & V & V & L & K & V & P & L & A & R & D & V & L & L\end{array}$ TGGT GGCCAAACGGTTACGGTCTCCA GAACCT GTACCA GAT GTCCGT GACCTTCACCTC TGGCTC TGACGT CTCCAGCCGCTCGTTCAAGGT TGGCTT CA

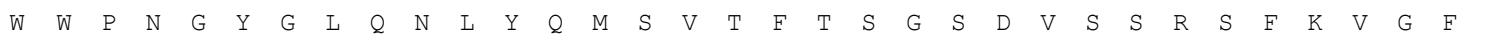
GGACA GTG GAGCTGATCCAA GACCCC GTGTCT TCC GACTCTAAGAAA GGCCTGACC TTC TAC TTCCGCATCAACGGTCTCCCGGTG TTCCTGAAA GGC TC

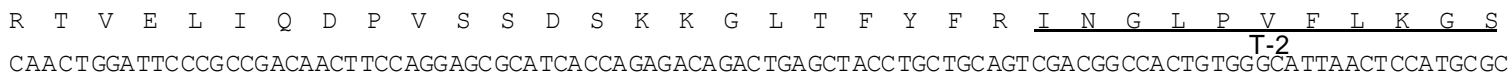

$\begin{array}{llllllllllllllllllllllllllllllllll}N & W & I & P & A & D & N & F & Q & E & R & I & T & R & D & R & L & S & Y & L & L & Q & S & T & A & T & V & G & I & N & S & M & R\end{array}$

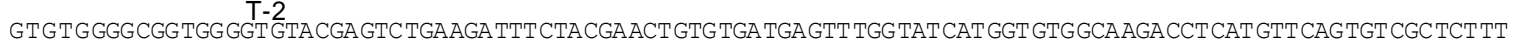

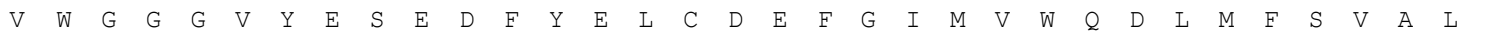
ACCCGACCTACGAT GGC TTCCTCCAGTCGGTGGCCACA GAGATCAGACAACAGGTCCAACGCCTCAAACACCACCCGTCCATCATTCTGTGGGCT GGCAA $\begin{array}{llllllllllllllllllllllllllllllllllll}Y & P & T & Y & D & G & F & L & Q & S & V & A & T & E & I & R & Q & Q & V & Q & R & L & K & H & H & P & S & I & I & L & W & A & G & N\end{array}$ CAACGAGAACGAGAAAGGTCTGCGCCAGAACT GGT TCAAAACACAGAACAACTTCACGC TCTATTACAACGATTATGTGAAGCTCTACGTCACAACCATC

$\begin{array}{llllllllllllllllllllllllllllllllllll}N & E & N & E & K & G & L & R & Q & N & W & F & K & T & Q & N & N & F & T & L & Y & Y & N & D & Y & V & K & L & Y & V & T & T & I\end{array}$ AAACCCATAGTAAACGCCGAGGA CGA CAGCCGTGA GTACCT TCT CTCCAGTCC TTCCAACGGCAAAGA GAG TGA GAAAGA GGG TTA TGT AGCCAA GGA GC

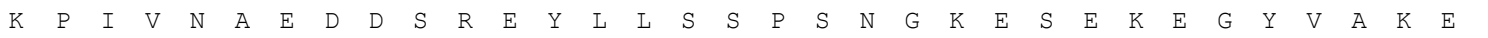
CTTGGAGT GAACTCTATGGA GACATTCATTTCTACGAAAACGTCGTGGATCAGTGGAACCCGGCCGTGTTCCGCGTGCCCCGCATGGCCTCA GAGTACGG $\begin{array}{lllllllllllllllllllllllllllllllllllll}P & W & S & E & L & Y & G & D & I & H & F & Y & E & N & V & V & D & Q & W & N & P & A & V & F & R & V & P & R & M & A & S & E & Y & G\end{array}$ CATACAGGGCT GGT GCAACAACGAGA GTCTGGCCTCAGTAT TCGCCCCAGAGGACTACA GCA TGGACGCGCCCATGA TAGGACACAGGCAGCATCATTAT

$\begin{array}{llllllllllllllllllllllllllllllllllll}I & Q & G & W & C & N & N & E & S & L & A & S & V & F & A & P & E & D & Y & S & M & D & A & P & M & I & G & H & R & Q & H & H & Y\end{array}$ AACGGCAACGC TGAAAT GGCAGCAGAAGT GGC TCT GCACATAGACTT GTCCAC TTCATCGGA TCC TGT CGT CAA GTT CACCGACTACATCTACCT TACAC $\begin{array}{lllllllllllllllllllllllllllllllllll}N & G & N & A & E & M & A & A & E & V & A & L & H & I & D & L & S & T & S & S & D & P & V & V & K & F & \frac{T}{C} & D & Y & I & Y & L & T\end{array}$ AGATCAACCAGGCCATGTCCATGCGT ACCCAGAGCGAGCAC TACAGGCGC TTCCAGTCCCGACTGCTC TCT GAT GGCCGCGGACTCACCATGGGCGCCCT

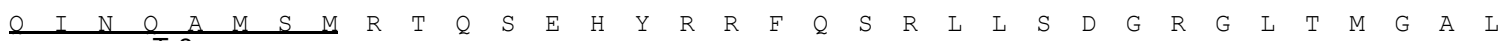

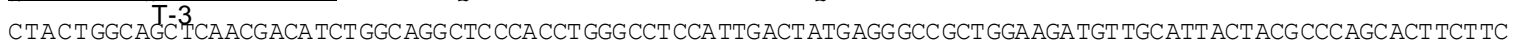

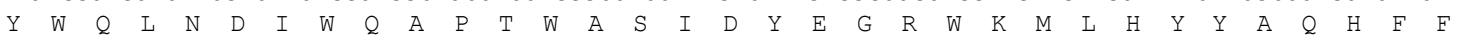

CAGCCCACCCT GGT GTCCCCGTACCT GCA GGACAACAACACCCTCAACGTCTTCATGGCCGTGGA TGGGGTCCCCAGTCT GGA GCGACGCGACAA TTT GA $\begin{array}{llllllllllllllllllllllllllllllllllll}Q & P & T & L & V & S & P & Y & L & Q & D & N & N & T & L & N & V & F & M & A & V & D & G & V & P & S & L & E & R & R & D & N & L\end{array}$ CAGGT GAACTGAGA TTT GAGCCCATGAGCGATATT GACGACATCAAGAAGAGCAGTATACACGCACAAGACGTC TCCGACACTTTGGCAGCCATTAACAA $\begin{array}{lllllllllllllllllllllllllllllllllll}T & G & E & L & R & F & E & P & M & S & D & I & D & D & I & K & K & S & S & I & H & A & O & D & V & S & D & T & L & A & A & I & N & K\end{array}$ AGCAACTTCCGGTCGTT TGACGGTGACCATGTACAATTACGCCA GTT TCACCCCCCTCAAGTCCT GGAATGTTGATTATTCGATGAACACAACGGCCGAC

$\begin{array}{llllllllllllllllllllllllllllllllllll}A & T & S & G & R & L & T & V & T & M & Y & N & Y & A & S & F & T & P & L & K & S & W & N & V & D & Y & S & M & N & T & T & A & D\end{array}$

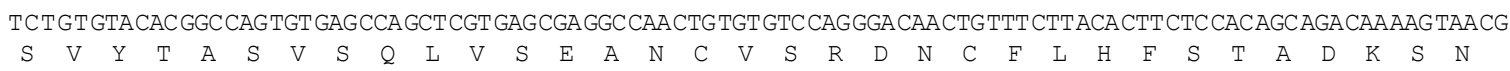
CCGT GACC TCCACC TCT TGGCTT TTCCTC TCT TACCCCAAG TAT TCCAAC TTGCCTCGA GCT CAAATCAAGGTGGTCGCA GTCAGGAACATC TCTCCACG $\begin{array}{lllllllllllllllllllllllllllllllllllll}A & V & T & S & T & S & W & L & F & L & S & Y & P & K & Y & S & N & L & P & R & A & Q & I & K & V & V & A & V & R & N & I & S & P & R\end{array}$ AGTTTTGGAAGTGGACATCTCCTCTGATGCTTTTGCTCTGTACGTCTGGC TATCTGCTGGGGACGTCC TGGGCAGGTTCTCGGATAACGGCTTTCACCTT $\begin{array}{llllllllllllllllllllllllllllllllllll}V & L & E & V & D & I & S & S & D & A & F & A & L & Y & V & W & L & S & A & G & D & V & L & G & R & F & S & D & N & G & F & H & L\end{array}$ CACACCCCGACAGCCACGGT CAA GTTCTA TGCCGCGGACGA TGT GACGGC TGCCAA GCT GCA GGGAAA TCT CAAAGT GAAAAG TTT GTCCGA TGTCCAA $\begin{array}{llllllllllllllllllllllllllllllllll}\mathrm{H} & \mathrm{T} & \mathrm{P} & \mathrm{T} & \mathrm{A} & \mathrm{T} & \mathrm{V} & \mathrm{K} & \mathrm{F} & \mathrm{Y} & \mathrm{A} & \mathrm{A} & \mathrm{D} & \mathrm{D} & \mathrm{V} & \mathrm{T} & \mathrm{A} & \mathrm{A} & \mathrm{K} & \mathrm{L} & \mathrm{Q} & \mathrm{G} & \mathrm{N} & \mathrm{L} & \mathrm{K} & \mathrm{V} & \mathrm{K} & \mathrm{S} & \mathrm{L} & \mathrm{S} & \mathrm{D} & \mathrm{V} & \mathrm{Q}\end{array}$

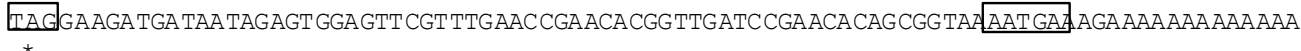

100

200

31

300 65

400

600 165

700

198

800

231

900 265

1000

298

1100 331

1200

365

1300

398

1400

431

1500

465

1600

498

1700

531

1800

565

1900

598

2000

631

2100

665

2200

698

2300

731

2400

765

2500

798

2600

831

2700

865

2800

898

2899

931

2985 


\section{Fig. 6}

A. kurodai

C.elegans

H. sapiens

A. aculeatus

A. kurodai

C.elegans

H. sapiens

A. aculeatus

A. kurodai

C.elegans

H. sapiens

A. aculeatus

A. kurodai

C.elegans

H. sapiens

A. aculeatus

A. kurodai

C.elegans

H.sapiens

A. aculeatus

A. kurodai

C.elegans

H. sapiens

A. aculeatus

A. kurodai

C.elegans

H. sapiens

A. aculeatus

A. kurodai

C.elegans

H. sapiens

A. aculeatus

A. kurodai

C.elegans

H.sapiens

A. aculeatus

A. kurodai

C.elegans

H. sapiens

A. aculeatus

A. kurodai

C.elegans

H.sapiens

A. aculeatus

A. kurodai

C.elegans

H.sapiens

A. aculeatus
MFWFHVS LLIATG ISQWML KTNNLVSSYERV--P LDGQLNWML SEA SAGVNI PASVPG SMYTALLEKNLI QDP LYRDNDNKYAWLGN MRT S LVVCLFWLLFQL HTT HGYNTLVNLAG------NWEF SSS NKTVNGTGTVPG DIY SDL YAS GI I DNP LFGENH LNL KWI AF MRLHLLLLLALCG----A GTTAAE LSYS-----LRG--NWSI CNGNGS LEL PGAVPGCVH SAL FQQ GLI QDS YYR FNDLNHRWV SL MRAL PT TATT LLGVLF FPS ASR SQYVRDLG- ---TEQWTLSSATLNRTVPAQFPS QVHMDLLRE GI I DEPYNDLND FNLRWI AD

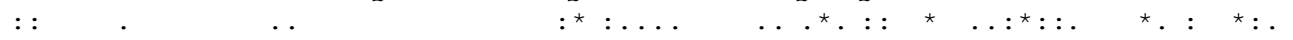
SDWTYNRNFTVSKSVAESSKVLLVCEGLDTVASVVVNGKAVGDTDNMFVRHAFDVTGI VKEGDNSIVVGERSAVLEAQERDQKSS-DDWTYSRKFRL-I DLDDTVGAF LEI ESVDTI ATVYVNGQKVLH SRNQFL PYHVNVTDI IAL GENDIT IKF KSSVKYAEKRADEYKKI DNWTYSKEFK IPFEIS KWQ KVN LILEGVDTVSKI LFNEVT IGE TDNMFNRYS FDI TNVVRD-VNSIE LRFQSAVLYAAQQSKAHTXANWTYTS GKI EGL GEDYES -TWLVF DGLDTF ASI SFC GQFVGA TDNQFRQYMFDVSSI LKA CPEEPT LGI QFGSAPNIVDAI AQDP$:{ }^{\star \star \star}$.

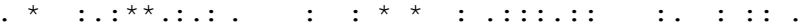

-- YE I PP NCP PPVQQGQCHVN--QLRKE QCS FSW DWG PSF PTQGIWKP-----------IY LNAFSTAVVQR--VSAIPKKVSGQWQ FGHS L PP DCN PDI YHGECHQN- -FI RKA QYS FAW DWG PSF PTVGIP ST- --- -- -- -IT INI YRGQYF HDF NWKTRF AHGKWKVA --YQVPP DCP PLVQKGECHVN--FVRKEQCS FSW DWG PSF PTQGIWKD-----------VR IEA YNI CHLNYFTFS PIY DKS AQEWN ----SSP TWPEGVQITYEY PNRWFMRKE QSDFGWDWGPAFAPA GPWKPGYVVQLKQAA PVYVRNTDLDIYRLGQINYLP PDQTQPWV

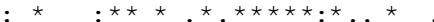
: : .

VDVDV IF DVNEGLTEVKGQVQVDVPALNLTLVQDVTVSSS QSRAKVVLKVPLARDVLLWWPNGY GLQNLY QMSVTFTSGSDVS--SR FEFDT FHYGARTI EYSVQI PELGIKESDYYRLSATKS LQTRSKNIMSLS I PMEHE PERWWPNGMGEQKLY DVVVSMGGQVKEK-- -LE I E S TF DVVS-S KPVGGQVIXAIP KLQ TQQ TYS IEL QPGKRI VEL FVN ISKNITVETWWP HGH GNQTGY NMTVLFELDGGLNI-EK VNAS LDY LGS LPENPS MAI EVKDLQ SGE ILASRP LTN ITVTEG SVT GVTVLE GVD PKLWWP QGL GDQNLYNVT ISVTDG GNQ SVAEV . . . $\quad: \quad: \quad: .:$ * $\quad * \star \star * *::$.

SFKVGFRTVELIQDPVSSDSK-K----GLTFYFR INGLPVFLKGSNWIPADNFQ-ERITRDRLSYLLQSTATVGINSMRVWGGGVYE - -K I GFKTVE LVQ DLI DPKKPEK----GRNFYFK INDEPVFLKGTNWIPVSMFRS DRENIAKTE FLLDSVAEVGMNAIRVWGGGFYE SAKVY FRTVELIEEPI KGS P-------GLSFYFK ING FPI FLKGSNWIPADS FQ-DRVTSELLRLLLQSVVDANMN TLRVWGGGI YE TKRT GFRTIF LNQRNI TDA QLA QGI APGANWHFEVNG HEFYAKGSNLIP PDC FW-TRVTED TMTRLF DAVVAGNQNMLRVWS SGA YI

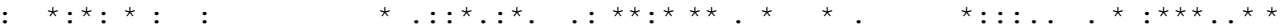

SEDFYELCDE FGIMVWODLMFSVALYPTYDG FLOSVA TEI ROOVORLKH HPS I ILWAGNNENEKGLRONWFKTON-NFT LYYNDYVK SNHFYYYASK KGI LVWQDLMFA CALYPT TEE FIQNAEEEV SYNVDR ISQ HTSVIVFSGNNE NEAAIRGHWWKA SNYTES QQVKDYVI QDEFYELCDE LGIMVWQDFMFA CALYPT DQG FLD SVTAEVAYQ IKRLKS HPS I I I WSGNNE NEEALMMNWYHI SFT DRP IYI KDYVT HDY I YDLADE KGI LLC SEF QFS DAL YPT DDA FLENVAAEVVYNVRRVNH HPS LALWAGGNE IES LML LLVEAADPE SYP FYVGEYEK

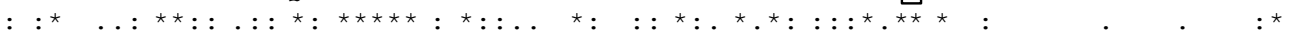
LYVTT IKPIVNAE DDSREYLLS SPSNG-------KESEKE GYVAKE PWSELYGDI HFYEN-VVDQWN PAV FRV PRMASEYGI QGWCN LYQR-LAKIAKKVAPT IPF IMS SPSNG-------VETEEE GGV SKN PYDVRY GDI HYYNE- FVNLWRDDTYLT PRCA. E YGVQSY PM LYVKN IRELVLAGDKSRPF ITS SPTNG-------AETVAEAWV SQN PNSNYF GDV HFY DY- ISDCWNWKV FPKARFA. EYGYQSWPS MY IS LFL PLVYENTRS ISYSPS STTEGY LDI DLSAPV PMAERY SNT TEGEYY GDT DHYNYDASI AFDYGTYPVGRF AN E FGF HSMPS

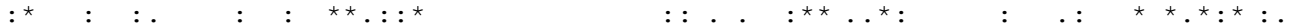
NES LA SVFAP-EDYSMDAPMIGHRQHHYNGNAEMAAEVALHIDLSTSS------------ -DPVVKFTDYIYLTQ INQAMSMRTQS KE TMLNW INE-SDWEYTSKAMF HRQ HHP GGI ATNLLMIFQHLP IPAECG SKS VSDVPS CKY ISS ASYMSRLAY FSQVHQ SIA LKT QT FSTLEKVSST-EDWSF NSK FSL HRQ HHEGGNKQMLYQAGL HFKLPQST------------- DP LRT EKDTIYLTQVMQAQCVKTET LQTWQQA LTD PAD LTFNSS VVMLRNHHY PAGGLMTDNYHNTVARHGRND PGR------ ---AGLLPDAQH SVR PRGQLQRLV PRD PA

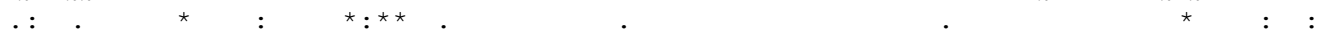

E HYRRFQ SRL LSD GRG LTMGAL YWQ LND IWQAPTWAS IDYEGR--- --WKML HYY AQH FFQPTLVSPYLQDNNTLNVFMAVD GVP SL LHYRRFRNTT TNE GLGNTMCAMYWQ LNDVWAAPTWST IDFEQN-----WKMAHYEARRFFSNVAVYS FADETD FNLKVF LLNDNPYI E FYRRSR SEI VDQ-QGHTMGAL YWQ LND IWQAPS WAS LEYGGK-----WKML HYF AQN FFA PLL PVG FENEN- --- -TFYIYGVS DI LPGG PLQVTN PVL PAGQRAART PARVPVLAARGH LAGALVGGDRVRRPLEGP HYVARD IYK PVI VSP FWNYTTGALDIYVTS DLWTA

$$
: \quad * \quad:: \quad: \quad: \quad * *::: \quad: \quad \text { : } \quad \text { : }
$$

ERRDNLT GEL RFE PMS DIDDIKKSS IHAQDV SDT LAA INKATS GRLTVTMYNYAS-FT PLKSWNVD-YSMN-T TADSVY TASVSQLV

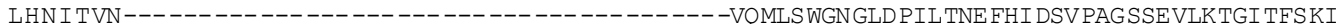
HS DY SMT ------------------------------LSVRVHTWSS - LE PVC SRVTER FVMKGGEAVCLYEEPVSELI AAGSVTLTWR---------------------------------DLS GKP IAS-NGGLP TKP LPF HVGALN STRLYRMNMKQQ PI

$$
: \quad: \quad: \quad: \quad: \quad:
$$

SEANCVSRDNCFLHFS TADKSNAVT STSWLF LSY PKYSN-LPRAQI KVVAVRNIS PRV LEVDIS SDAFAL YVWLSAG-DVLGRFS DN TELSEYLYVS TLY DSS GVK IHE DVLVPDFLFEVD FNT FG-----DVQIS DVQRIDEKTYDLTITTDRVSP FTW ITCKKP FTGWFS DN RRCGNCTRESCVVSFY LSA DHELLS PTNYHF LSS PKEAVGLCKAQI TAI ISQ--QGDI FVF DLE TSAVAP FVWLDVG-S IPGRFS DN

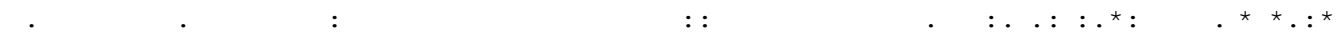
GFHLHTPTATVK-FYAADDVTAAKLQGNLKVKSLSDVQ--GFHMI QRLRK IR-LIAKFEVDLE--KSDFTVCNLKNCYV- GFLMTEKTRT IL- FYPWEPTSKNELEQS FHVTSLTDIY--SFVVVPGQKKVVG FVVQADETDGEWVHDVTVRSLWDLNEGE * : . . : : ..* .* : 